Review Article

\title{
Nanofeatured Titanium Surfaces for Dental Implantology: Biological Effects, Biocompatibility, and Safety
}

\author{
Ruggero Rodriguez y Baena, ${ }^{1}$ Silvana Rizzo, ${ }^{1}$ Luigi Manzo, ${ }^{2}$ and Saturnino Marco Lupi ${ }^{1}$ \\ ${ }^{1}$ Department of Clinical-Surgical, Diagnostic and Pediatric Sciences, University of Pavia, Piazzale Golgi 2, Pavia, Italy \\ ${ }^{2}$ Pharmacology and Toxicology Unit, Department of Clinical-Surgical, Diagnostic and Pediatric Sciences, \\ University of Pavia, Piazzale Golgi 2, Pavia, Italy \\ Correspondence should be addressed to Ruggero Rodriguez y Baena; ruggero.rodriguez@unipv.it
}

Received 15 December 2016; Revised 14 April 2017; Accepted 9 May 2017; Published 4 June 2017

Academic Editor: Martin Andersson

Copyright (c) 2017 Ruggero Rodriguez y Baena et al. This is an open access article distributed under the Creative Commons Attribution License, which permits unrestricted use, distribution, and reproduction in any medium, provided the original work is properly cited.

\begin{abstract}
Nanotechnology enables the control and modification of the chemical and topographical characteristics of materials of size less than $100 \mathrm{~nm}$, down to $10 \mathrm{~nm}$. The goal of this review is to discuss the role of titanium substrates as nanoscale surface modification tools for improving various aspects of implantology, including osseointegration and antibacterial properties. Techniques that can impart nanoscale topographical features to endosseous implants are described. Since the advent of nanotechnology, cellular specific functions, such as adhesion, proliferation, and differentiation, have been better understood. By applying these technologies, it is possible to direct cellular responses and improve osseointegration. Conversely, modulating surface features by nanotechnology could have the effect of decreased bacterial colonization.
\end{abstract}

\section{Introduction}

The modern implantology was developed in the late 1960 based on the studies of Branemark, which led to the concept of osseointegration. Osseointegration is defined as the direct contact between the vital bone and the implant at the microscopic level [1-3]. Initially, titanium implants with machined surfaces were used and the healing time before prosthetic charge was empirically established within 3-6 months. Although these results represented a relevant advancement, some issues remained regarding primary osseointegration rates, especially in some categories of patients, such as those considered at risk (e.g., diabetics and smokers) [4-8].

Apart from the cases considered at risk for the general health status of the patient, implants placed in sites treated with bone regeneration procedures $[9,10]$ may benefit from the surface treatments that create nanometric osteoconductive features. Titanium, in particular, has initially been identified as the gold standard for dental implants due to its favorable physiochemical and biological characteristics [1113].
Osseointegration, similar to bone fracture healing, involves many complex physiological mechanisms, such as the development through hemostasis, the organization of the clot and fibrin polymerization, neoangiogenesis, the deposition of an extracellular matrix, the colonization of bone-forming cells, and the formation of the osteoid tissue. These occur until the mineralized bone matrix and bone-implant are in direct contact with each other [14]. Osseointegration is most affected by the implant surface, because it encompasses the surface area, mineralization, and the mechanical relationship of direct bone-to-implant contact (BIC) [15-19].

In the 1990s, much focus was placed on topographical micrometric features, noting an increase of osseointegration, BIC, and resistance to applied loads [20] on sandblasted and etched surfaces. This leads to the understanding that osseointegration could indeed be influenced by various surface features [21].

The interaction between a microcharacterized implant surface and the bone has been explained according to three different theories: biomechanical, contact osteogenesis, and 
osteodifferentiation. The first, expressed as a mathematical model described by Hansson and Norton [22], considers the relationship between the bone and the implant from a purely mechanical point of view. It takes into account the shape and density of pits on the surface, and according to this theory, the optimal pit values were calculated to be approximately $1.5 \mu \mathrm{m}$ in depth and $3-5 \mu \mathrm{m}$ in diameter. This theory, supported by subsequent findings [23-26], emphasizes the importance of mechanical retention and the forces distributed to obtain maximal osseointegration.

According to the theory of contact osteogenesis as proposed by Davies [27], a microrough surface allows for the optimal activation of the platelet factors, followed by the stabilization of the fibrin cloth and, finally, the direct growth of osteoblasts onto the implant surfaces [28]. Afterwards, numerous studies confirmed that an increase in the surface topography corresponded to an increase in extracellular matrix production and, finally, that of osseointegration [2941].

According to the second theory, that of osseodifferentiation, the interaction between the implant surface with specific features and the adherent cells induces a preferential differentiation towards the osteoblastic line, for example, through adhesion or shape transformation [21, 29, 42-44].

Current research efforts are aimed at providing osteogenic features to implant surfaces for guiding the differentiation of adherent progenitor cells and enhancing osseointegration. For this purpose, surface modifications including microtopographical and chemical ones, or characterization with bioactive molecules, such as bone morphogenetic proteins (BMPs), have been proposed, and interest has focused primarily on modifications providing nanometer-level resolution [45-47].

Nanoscale surfaces are regarded as those with structures smaller than $100 \mathrm{~nm}$ in at least one dimension, and nanofeatures have been characterized on at least four commercially available implants [48].

Controlling surface features at a nanometric level allows for product surfaces that more naturally emulate biologic environment, which is regulated by nanometric scale components. Nanoscopic modifications to dental implants could affect the physicochemical and topographical features, as well as surface characteristics secondary to the deposition or adsorption of nanoscale complexes. In this review aspects regarding technology production and capability to stimulate a correct osteogenetic response by host tissue and bacterial response to nanofeatured implant surfaces are discussed.

\section{Discussion}

2.1. Nanotechnology and Surface Science. Nanotechnology spans the creation of functional materials, devices, and systems by controlling matter on the nanometer scale $(<100 \mathrm{~nm})$ and utilizing the novel phenomena and properties (physical, chemical, and biological) which occur on this scale [49]. It involves one-dimensional (nanodots), twodimensional (nanowires), or three-dimensional (nanotubes) spatial structures, and accordingly, these materials can be nanostructures, nanocrystals, nanocoatings, nanoparticles, or nanofibers [50]. The application of nanotechnology to implants can confer new physicochemical or biochemical characteristics (e.g., binding to bacterial plaque, adsorption of proteins) that are not observed on larger scales [51].

Several techniques can be used for nanofeaturing titanium implant surfaces [52].

\subsection{Physical Techniques}

2.2.1. Compaction of Nanoparticles. Nanoparticles of $\mathrm{TiO}_{2}$ can be packed onto titanium surfaces to obtain nanoscale granules. This technique was reported to increase the osteoblast adhesion with no reported changes being incurred on the physiochemical characteristics of the material [37].

2.2.2. Grit Blasting. Bioceramic grit blasting and acid etching technologies have been used in combination to produce nanometric textures on titanium implants. These surfaces have a favorable effect on initial bone healing processes $[54,55]$. The materials used for blasting include aluminium oxide $\left(\mathrm{Al}_{2} \mathrm{O}_{3}\right)$ or silicon carbide $(\mathrm{SiC})$. The final morphology of the surfaces can be modified by particles of different compositions and sizes [56]. Smaller particles can adhere to the implant even after ultrasonic cleaning, acidic passivation, and sterilization because of the high impact velocity between small particles and implant surfaces $[57,58]$. Blasting with $\mathrm{TiO}_{2}$ has been proposed as a procedure to prevent the contamination of implant surfaces and increase both osteoblast adhesion and osteogenic differentiation $[59,60]$.

\subsection{Chemical Techniques}

2.3.1. Anodic Oxidation. Anodic oxidation or anodization is a method commonly used in the industry to create surfaces with nanometer topography, such as holes, pits, or pipes [61, 62] (Figure 1). In this treatment, direct current flows through an electrolytic solution from a titanium anode to a cathode, typically of platinum, allowing for the generation of regular and repeatable structures on the titanium surface. The diameter of the structures and the distances between them can be adjusted by controlling the intensity of the current. This technique has been used to produce nanotubes with diameters between 15 and $100 \mathrm{~nm}$ [63]. Small nanotubes (30 $\mathrm{nm}$ in diameter) can promote osteoblastic adhesion without noticeable differentiation, whereas larger nanotubes (70 to $100 \mathrm{~nm}$ in diameter) elicit a dramatic stem cell elongation (10-fold increase), causing cytoskeletal stress, and selective differentiation into osteoblast-like cells $[62,64]$. Studies have also shown that nanotubes with a diameter between 50 and $100 \mathrm{~nm}$ enhance osseointegration, $\mathrm{BIC}$, and bone morphogenetic protein 2 (BMP-2) expression more efficiently compared to smaller nanotubes [65]. In vivo studies showed more pronounced osseointegration when surfaces contained nanotubes compared to smooth surfaces [66], but no attempts were made, in these experiments, to compare nanosurfaces with microfeatures. It is postulated that titanium-based nanotubes allow a greater deposition of hydroxyapatite in comparison to nanoparticles [61]. 

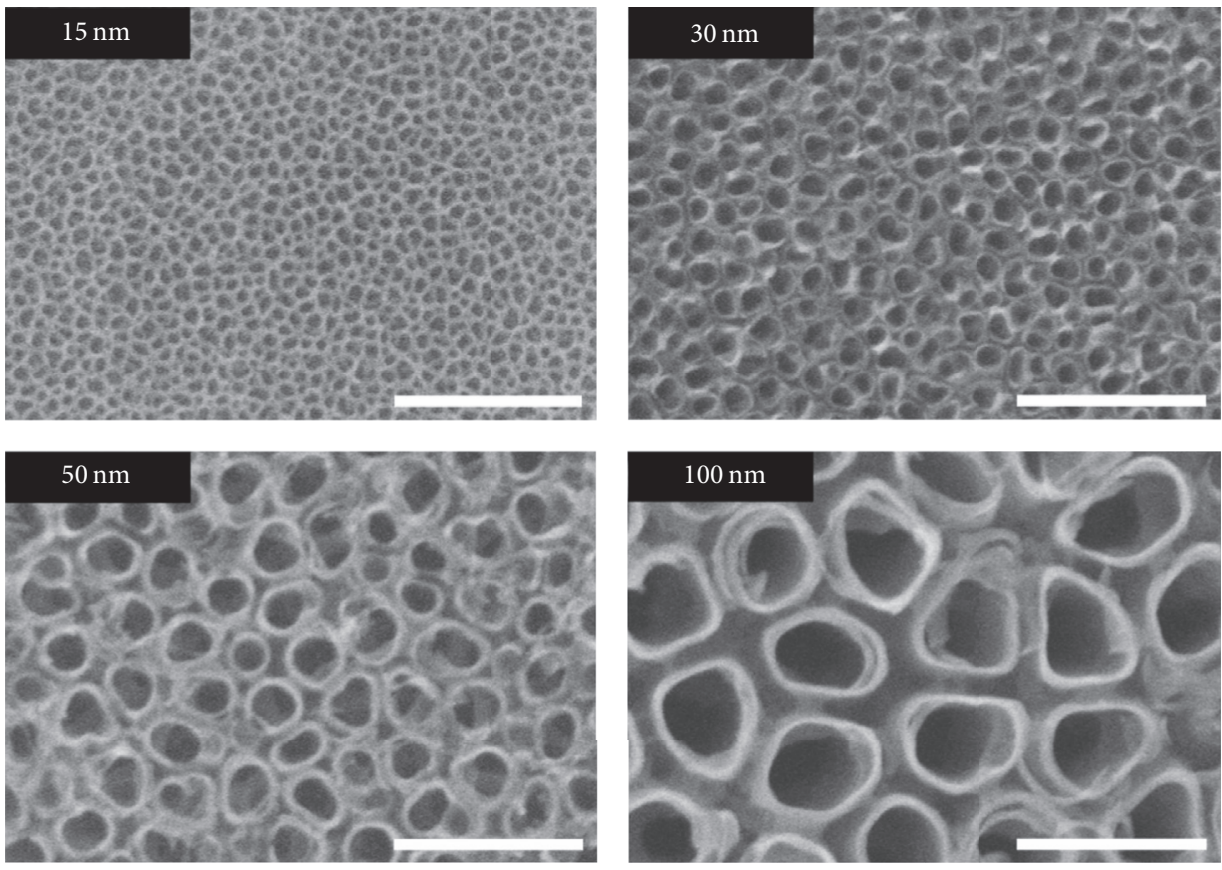

FIGURE 1: SEM images of vertically oriented $\mathrm{TiO}_{2}$ nanotubes of different diameters. Scale bars: $200 \mathrm{~nm}$. Reproduced from [53] with permission from The Royal Society of Chemistry.

Through anodization highly ordered porous $\mathrm{TiO} 2$ nanotubes with great uniformity, controllable pore size can be obtained by controlling of some parameters, like electrolyte composition, anodization time, anodization voltage, electrolyte temperature during anodization, interelectrode spacing, metal substrate, pre- and posttreatments, and annealing. For a detailed analysis of these parameters see the review by Kulkarni and Coll. [63]. An advantage of the anodic oxidation process is that entities from the electrolytic solution, such as calcium, can be incorporated in the oxide layer [62]. Moreover, through the anodization process, titanium surfaces can be covered by a thin layer of another material, like silver, which possesses antibacterial properties [67]. An in vivo study compared three surfaces: a machined surface, an $\mathrm{HCl}$-treated surface, and an $\mathrm{HCl}$-treated, anodized surface. The HCl-treated/anodized surface showed superior results regarding bone density, number of trabeculae, pull-out forces, and BIC [68]. There is a growing body of data that demonstrates the benefits of using $\mathrm{TiO}_{2}$ nanotubes for enhanced orthopedic implant surfaces [69].

2.3.2. Acid Oxidation or Peroxidation. The rationale for using acid oxidation and peroxidation to nanoscopically texture metals is to permit simultaneous etching and oxidation of the surface in a controlled manner [17]. For orthopedic implantology, titanium is generally used in these processes, but other metals such as tantalum (Ta) or chromium-cobaltmolybdenum alloys (CrCoMo) have also been used [50]. For dental implantology, it is possible to obtain nanopits, sized $20-100 \mathrm{~nm}$, on the titanium surface with a treatment of strong acids, such as $\mathrm{H}_{2} \mathrm{SO}_{4} / \mathrm{H}_{2} \mathrm{O}_{2}$ or $\mathrm{HCL} / \mathrm{H}_{2} \mathrm{O}_{2}$ or $\mathrm{HF} / \mathrm{H}_{2} \mathrm{O}_{2}$ [53] (Figure 2). Moreover, varying the acidic (or basic) component in mixtures containing $\mathrm{H}_{2} \mathrm{O}_{2}$ appreciably changes the nanopatterns on $\mathrm{Ti}$ surfaces [70]. $\mathrm{H}_{2} \mathrm{O}_{2} / \mathrm{HCl}$ processing adjoined to adequate thermal cycles produces a titanium gel coating that favors apatite deposition in vitro [71]. Oxidation in $\mathrm{H}_{2} \mathrm{O}_{2} / 0.1 \mathrm{M} \mathrm{HCl}$ at $80^{\circ} \mathrm{C}$ resulted in a good adhesion of arginine-glycine-aspartic acid peptides as well as the calcified matrix formation of rat bone marrow stromal cells [72]. Several studies demonstrated the ability of $\mathrm{HF}$ acid, when treated on $\mathrm{TiO}_{2}$ grit-blasted $\mathrm{Ti}$ implants, to enhance the osteoinductive function, differentiation from mesenchymal stem cells into osteoblasts, and early osseointegration $[30,35,73,74] . \mathrm{H}_{2} \mathrm{SO}_{4} / \mathrm{H}_{2} \mathrm{O}_{2}$ creates a nanopattern which has been demonstrated in vivo to be linked with an enhanced proliferation of essential osteoblastic cells and the simultaneous inhibition of unwanted fibroblastic cells [75]. It has also been observed that $\mathrm{H}_{2} \mathrm{SO}_{4} / \mathrm{H}_{2} \mathrm{O}_{2}$ oxidative nanopatterning promoted the differentiation of stem cells. Unlike the etching of Ti with $\mathrm{H}_{2} \mathrm{SO}_{4} / \mathrm{H}_{2} \mathrm{O}_{2}$, treatment with $\mathrm{NH}_{4} \mathrm{OH} / \mathrm{H}_{2} \mathrm{O}_{2}$ created nanoporosity without increasing the thickness of the original oxide layer and did not increase the osteoinductive properties [70].

\subsubsection{Alkali Treatment. Implant surfaces treated with $\mathrm{NaOH}$} produce a nanoscale topography which exposes the surface active groups through the formation of a sodium titanate gel [76]. This gel can turn into anatase by simple hydrothermal treatment, giving rise in the authors opinion to highly bioactive surfaces [77].

Surfaces obtained by various technologies can be treated with $\mathrm{NaOH}$ to increase their reactivity. For example, nanotubes treated with $\mathrm{NaOH}$ obtained by anodization, or macroporous Ti surface layer formation by plasma spraying, 


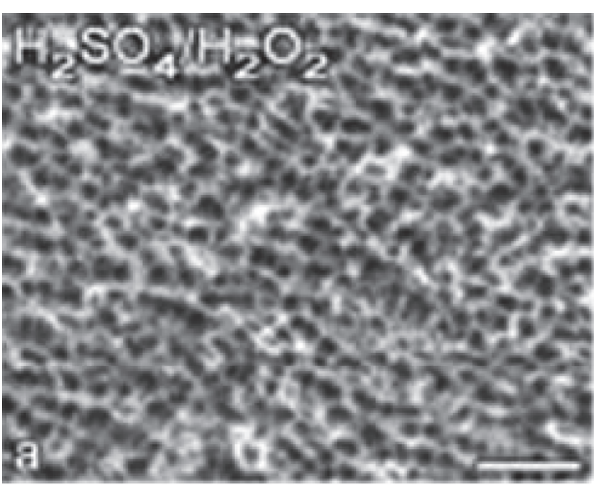

(a)

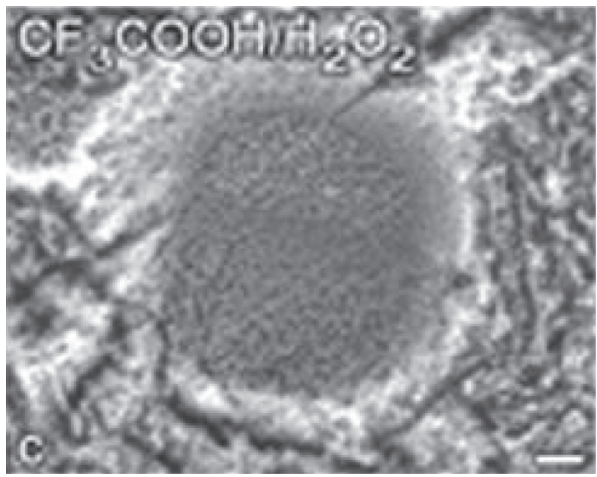

(c)

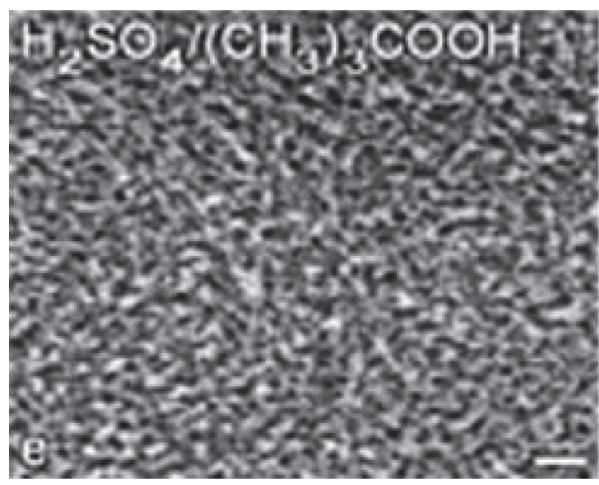

(e)

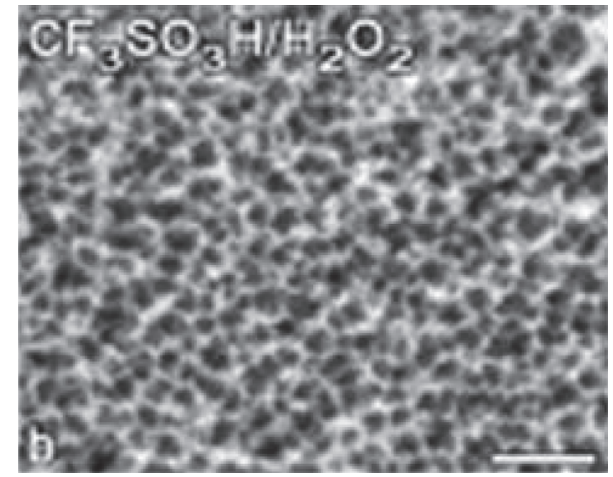

(b)

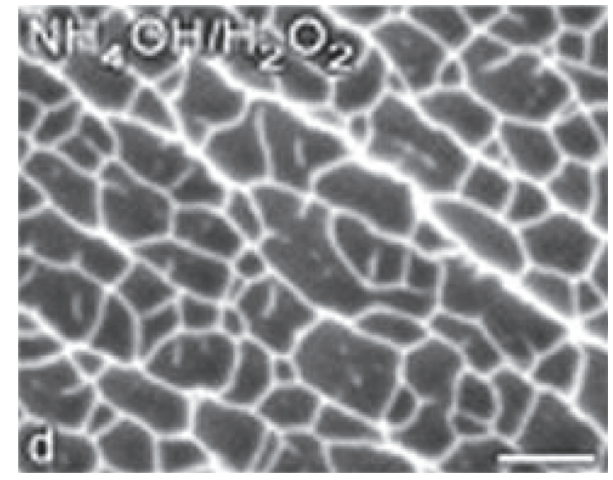

(d)

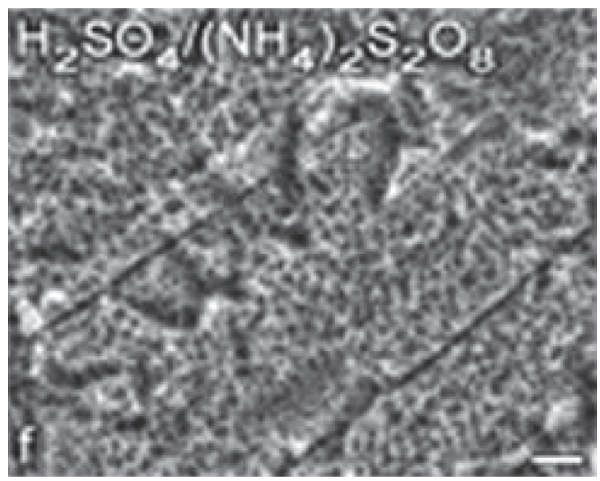

(f)

FIgure 2: Characteristic SEM images of Ti surfaces nanostructured by oxidative etching with different solutions (scale bar $100 \mathrm{~nm}$ ). Reproduced from [53] with permission from The Royal Society of Chemistry.

are converted into a bioactive sodium titanate layer that can induce the formation of a bone-like apatite in simulated body fluid [37, 78]. $\mathrm{NaOH}$-treated surfaces can subsequently be silanized to achieve antibacterial features [67]. $\mathrm{NaOH}$ treatment in combination with heat treatment produces nanotrabecular and nanotuft-like structures and enhances osteoconductivity [79].

2.3.4. Alkali-Acid Treatment. Titanium surfaces can be altered by sequential treatment with $\mathrm{NaOH}, \mathrm{HCl}$, and thermal cycles leading to a titanium oxide layer of anatase and rutile phases that was shown, in vitro, to possess high apatiteforming abilities [80, 81].

\subsection{Coating Techniques}

2.4.1. Sol-Gel Coating. A solution from alkoxides, metal salts, or other suitable precursor is deposited on the substrate by either dip, spin, or spray coating. Exposed to water, hydroxides or hydrated oxides form and gelation occurs, and further heating produces an oxide layer without residual organic material. The sol-gel coating method enables the coating of an implant surface by a layer of sol-gel containing hydroxyapatite, which is stabilized through thermal cycles [82-85]. The coating can also contain fluorohydroxyapatite or fluorapatite to increase the biological activity and reduce resorption rate of the coated layer [86-88]. Sol-gel derived nanoporous $\mathrm{TiO}_{2}$ coatings have been proven to enhance soft 
tissue attachment in rat and dog models [89-91]. Similarly, in a human experimental study, results indicated that a significantly greater proportion of oral mucosa came into contact with the nanoporous $\mathrm{TiO}_{2}$ surface than that with the unmodified surfaces [92]. This technique is also used to coat bone substitutes with a nanolayer of osteoconductive material [93].

2.4.2. Self-Assembly of Monolayers (SAMs). Molecular selfassembly allows for the deposition of a self-assembled monolayer onto a substrate and subsequent exposure of an active terminal group that promotes specific biological functions such as the adhesion of protein and cells [94] or bone deposition [95]. This technique sounds promising because it allows obtaining a selective adhesion to the surface. For example, osteoblasts can be favored and bacteria disadvantaged. In vivo results, however, showed contradictory data. In fact, although BIC was significantly higher in SAMs than in standard titanium surfaces at two weeks, at four weeks the traditional surface showed a greater BIC. Therefore, further studies should be conducted before this technology can be used in humans [95].

2.4.3. Plasma Spray. Plasma spray coatings are used in a wide range of industries, such as the automotive, aerospace, and petroleum industries, to name a few [96]. With this technology, the coating material, generally a powder, is heated to high temperatures for a very short period of time and is then accelerated against the substrate, where the coating is then formed [97]. Plasma spray technology allows a substrate to be coated with various types and layers of different materials and to obtain an array of nanostructures with features smaller than $100 \mathrm{~nm}$. Hydroxyapatite is a frequently used coating material in implant dentistry [98] due to its ability to stimulate rapid biological responses [99-103]. Problems with this technology are related to the production process, where high temperatures are required. This leads to the modification of hydroxyapatite to generate the more unstable, water-soluble products of $\mathrm{CaP}, \alpha$-tricalcium phosphate, and $\beta$-tricalcium phosphate $[98,99,104-107]$. The coating is not very adherent to the substrate and can easily degrade, losing its biological stability [98]. Moreover, problems related to strength and resistance to fatigue may arise. Similar to the plasma spray technique, the high velocity of oxy-fuel combustion spraying allows for the formation of a coating layer of hydroxyapatite powders. This technique also has limitations arising from aqueous solubility and coating detachment [108].

2.4.4. Ion Beam Deposition. Ion beam deposition can be applied to overcome the limitations of the plasma spray technique by depositing of a very thin layer of osteoconductive bioceramic material onto the implant surface. The very thin layer could allow for a more gradual exposure of the implant surface, which is more aligned with the rate of bone growth $[98,109]$.

2.4.5. Pulsed Laser Deposition. Coating with hydroxyapatite layers can also be obtained through laser treatments, which increases the bond strength between the coating and the substrate [110]. This method allows coating a substrate with hydroxyapatite vapor obtained by heating an hydroxyapatite target with laser. Quality of the coat depends greatly on processing parameters and the whole procedure is not plain.

2.4.6. Electron Beam Evaporation. High energy electron beam bombardment on the source material to be deposited produces large amounts of heat that vaporize atoms and molecules of the coating material. The generated vapor is directed to the top of the vacuum chamber and coats the substrate, generating a layer that masks the original surface. A study reports for this technique a rate of deposition of $3.0 \AA / \mathrm{s}$ and at a thickness of $500 \mathrm{~nm}$, obtaining a coating that contains nanosize grains [111].

2.4.7. Deposition of a Supersonic Beam of $\mathrm{TiO}_{x}$ Clusters. This technique is based on the ablation of a titanium rod by a helium plasma jet, ignited by a pulsed electric discharge. $\mathrm{TiO}_{x}$ ions condensed to form clusters form a seeded supersonic beam, which is collected on a substrate located in the beam trajectory [112]. This surface demonstrated the capability to promote human bone marrow mesenchymal stem cells osteoblast in an in vitro study $[113,114]$.

2.4.8. Discrete Crystalline Deposition. This method allows for the deposition of discrete calcium phosphate nanoparticles $(20-100 \mathrm{~nm})$ on a titanium implant with predisposing substrate microtopography produced by acid etching. This is done to obtain a bioactive surface and an increased mechanical interlocking with the surrounding bone. The deposition is achieved by immersing the metallic implants in a suspension of calcium phosphate nanoparticles followed by thermal cycles to result in approximately $50 \%$ of the metallic surface being covered by the nanoparticles, with the remaining surface being metal oxide [115].

2.4.9. Electron Beam Lithography. Electron beam lithography has been used to fabricate ultra-precise nanotopographies of ordered arrays less than $10 \mathrm{~nm}$ in size [116]. The advantages of this method are illustrated by recent studies comparing the effects of periodic arrays of nanopores created by electron beam lithography with those of disorganized arrays of the same nanopores. The results indicated that the haphazard arrangement was better for stimulating the differentiation of human mesenchymal stem cells into osteogenic cells [117].

2.4.10. Lithography and Contact Printing. Colloidal lithography has been used to fabricate controlled, well-defined nanoscale surface topographies [118-120]. Titanium-coated hemisphere-like topographical nanostructures sized 50$200 \mathrm{~nm}$ are able to influence the morphology, proliferation, and osteogenic differentiation of human mesenchymal stem cells [121]. Recently, a significant enhancement in bone formation was detected on Ti implant surfaces modified by $60 \mathrm{~nm}$ hemispheres, suggesting that bone formation is in fact dependent on the size of the nanofeatures [122]. Moreover, an implant with hemispheres of $80 \mathrm{~nm}$ was found to attenuate 
the inflammatory response while enhancing mineralization during osseointegration [123].

2.5. Biochemistry. Surface characterization at nanoscale level can alter also the chemical organization of matter. Some study with X-ray diffraction identified altered crystal structures in nanophase compared to conventional titania compacts. Conventional titania possessed an exclusively rutile phase, while nanophase titania was a mixture of anatase and rutile [124]. Since ceramic crystal structure as well as surface roughness promotes osteoblast function [125], nanophase titania can improve bone formation.

2.6. Biomimetics. The ability to control $3 \mathrm{D}$ features at nanolevel allows better replication of natural cellular environment, which is regulated by molecular behavior at nanoscale. For example, the major inorganic component of bone, hydroxyapatite, is between 2 and $5 \mathrm{~nm}$ in width and $50 \mathrm{~nm}$ in length while the major organic component of bone, collagen I, is a triple helix, $300 \mathrm{~nm}$ in length, $0.5 \mathrm{~nm}$ in width, and has a periodicity of $67 \mathrm{~nm}$ [125]. Also the surface roughness of natural bone possesses nanometric features and nanophase titania can better replicate them. A study evaluated the roughness of bone, conventional titania, and nanophase titania [124]. The root-mean-square surface roughness values of bone are in the range of $25-32 \mathrm{~nm}$, while those of conventional titania and nanotitania are in the range of $11-12 \mathrm{~nm}$ and $22-29 \mathrm{~nm}$, respectively.

2.7. Nanotopography Altered Cellular Responses. Nanostructured surfaces affect the mechanical properties of cells and may provide new methods for altering the response of cells to external signals [120,124, 126-128]. Surface nanotopographies and chemistries confer to the material unique properties that modify cell adhesion processes by direct (cell-surface interactions) and indirect (affecting protein-surface interactions) mechanisms [47].

2.8. Protein/Surface Interactions: Surface Wettability. Protein adsorption has been found to be a key factor in determining the peculiar behavior of cells on nanostructured surfaces $[129,130]$. By modifying the surface energy or wettability of the surface, the adsorption of proteins is influenced, and the interactions of cells with the surface can therefore be altered.

The adsorption of fibrinogen and platelet adhesion, for example, is inversely related to the hydrophilicity of the surface $[94,131]$. In a study, the authors found that cells were unable to adhere to hydrophobic surfaces previously coated with albumin but could easily adhere to hydrophilic surfaces covered with albumin [132].

The initial protein-surface interaction may explain the greater adhesion of osteoblasts on nanoscale substrates as a critical aspect of the osseointegration process. Surface effects are often mediated through integrins, with the vitronectin receptor being the predominant form of integrin receptor involved in substrate adhesion [133]. Vitronectin is strongly adsorbed onto nanoscale substrates [134], contributing to the enhanced adhesion of osteoblasts. Proteins that contain the Arg-Gly-Asp (RGD) attachment site, together with the integrins that serve as receptors for them, constitute a major recognition system for cell adhesion [135]. The distribution and density of RGD regulate effective cell spreading, formation of focal adhesions [136], and cell motility [137]. Surface changes that modify the RGD binding have been suggested to be a key factor in altering osteoblastic differentiation [138]. However, the relevance of this mechanism is still controversial. For example, Cai et al. reported that the absorption of albumin and fibrinogen and the proliferation and viability of osteoblasts did not differ in titanium surfaces with surface roughness values of 2 to $21 \mathrm{~nm}$. This indicated that albumin and fibrinogen adsorption processes were unaffected by changes in roughness within that range [139].

2.9. Cell Adhesion, Spreading, and Motility. Nanoscale features play a critical role in both cell adhesion and cell motility. Reactions of cells to surface topographies include changes in cell orientation, cell motility, cell adhesion, and cell shape [140]. As previously described, integrin receptors modulate the adhesion between cells and extracellular matrices. In addition, integrin activation can affect cell functions such as motility, proliferation, and differentiation by initiating multiple intracellular signaling pathways [141]. Cell motility may be regulated by varying the ligand spatial presentation at the nanoscale level, and integrin ligand clustering is required to support cell locomotion [137]. An increased surface charge density at highly curved surfaces and sharp edges can explain the mechanism of adhesion between the negatively charged titanium surface and a negatively charged osteoblast, mediated by charged proteins with a distinctive quadrupolar internal charge distribution, fibronectin, and vitronectin [142, 143]. Nanofeatures of an alloplastic surface may have unique attributes affecting cell interactions. Both the dimension and the density of nanofeatures can affect the cell behavior [140]. Currently, the smallest dimension recognized by a eukaryotic cell is approximately $10 \mathrm{~nm}$ [144].

On flat titanium surfaces containing submicrometerscale roughness produced by chemical etching or porous anodization, cells exhibit a greater thickness and delayed appearances of focal contacts compared to smooth, polished, and electropolished surfaces. Submicrometer-scale roughness favors the formation of long, numerous filopods. In an in vitro study on titanium substrata, the addition of nanotopography onto microtopography led to the presence of more focal contacts distributed throughout the entire cell surface. Microscale and nanoscale roughness exert synergistic effects on cell proliferation [145]. The growth and spatial orientation of cells were controlled in vitro by substrates with nanoscale features, showing that substrates with specific nanofeatures can in fact direct cell growth [146-148].

In this respect, there are, however, dissenting opinions. In studies examining various substrates with $24,50,200$, and $1500 \mathrm{~nm}$ grain size, Dulgar-Tulloch et al. observed that human mesenchymal stem cells (HMSCs) adhesion on alumina and hydroxyapatite were significantly reduced in the materials with 50 and $24 \mathrm{~nm}$ surfaces, as compared with the 1500 and $200 \mathrm{~nm}$ surfaces. Conversely, the adhesion on titanium substrates was found to be independent of grain size [149]. 
In another study [117], highly ordered nanotopographies produced low to negligibly low cellular adhesion and osteoblastic differentiation, whereas nanodisplaced topographies significantly increased the osteospecific differentiation. This suggests that the use of disorder may be an effective strategy in the development of materials for regenerative medicine and tissue engineering.

2.10. Proliferation. Nanoscale features can affect cell proliferation, although experimental evidence is not univocal. Several studies indicated that nanostructures on titanium oxide surfaces could enhance cell adhesion and proliferation $[112,144,150]$.

In a study [148], titanium surfaces with microdefects produced by photolithography and nanodefects produced by acid etching or anodizing and combinations of these surfaces were compared to assess the response of osteoblasts to nano-, micro-, or combined surfaces. Acid etching produced a peaky and pointy morphology, whereas anodizing produced a sponge-like surface with belt-like rings around the pore openings. Smooth surfaces showed the highest cell proliferation, while nanofeatured surfaces showed the highest osteoblast differentiation and osteogenic activities [151].

Webster et al. evaluated the activity of osteoblasts and osteoclasts cultured on nanophase ceramics and compared them to conventional ceramics $[39,152]$. They observed a lower surface occupancy of osteoblast colonies, as well as a greater cell proliferation, osteogenic activity of osteoblasts, and activity of osteoclasts on nanophase ceramics.

In a previous study done [149], HMSC proliferation was minimal on 50 and $24 \mathrm{~nm}$ substrates of any chemistry tested and thus significantly lower than the densities observed on either the 1500 or $200 \mathrm{~nm}$ surfaces after three or more consecutive days of culture. Furthermore, HMSC proliferation was enhanced on the $200 \mathrm{~nm}$ substrates, compared with results obtained on the $1500 \mathrm{~nm}$ substrates after seven or more days of culture. Moreover, rat osteoblast and fibroblast adhesion and proliferation exhibited similar trends to those of HMSCs on all substrates tested.

Realistically, nanofeatured surfaces allow for more effective cell adhesion to the substrate, reducing expansion and cell flattening and therefore reducing the surface coverage. However, cells grown on the nanosurfaces have a greater differentiation and osteogenic activity.

2.11. Selectivity of Adhesion. An important observation is that nanosurfaces can selectively promote cell adhesion. An example of this selective response was described by Dulgar-Tulloch et al. in studies examining a nanophase ceramic/polymer composite that was effective in promoting osteoblast adhesion but prevented and/or minimized fibroblast adhesion [153]. In another study, this difference was not observed [149]. Moreover, nano- and submicron surface features reduced the adhesion of and proinflammatory cytokine release from macrophages and immune cell responses after implantation [154].

Notably, nanophase $\mathrm{ZnO}$ and $\mathrm{TiO}_{2}$ may reduce Staphylococcus epidermidis adhesion and increase osteoblast functions necessary to promote the efficacy of orthopedic implants [155]. The importance of selective adhesion will further be discussed in the bacterial accession section.

2.12. Differentiation. Some studies have shown that increased cell differentiation takes place on the nanoscale surface [30, 156]. Huang et al. evaluated the response of osteoblastlike cells on microcrater, nanoplate, and nanoleaf surfaces obtained by microarc oxidation [157]. The adherent cells were polygonal-shaped on the microcrater surface, roundish on the nanoplate surface, and elongated on the nanoleaf surface. The distortion of cell nuclei was noticed only on nanoleaf surfaces. Compared with microcrater surfaces, nanoplate surfaces slowed down cell proliferation, while nanoleaf surfaces supported it. Cell differentiation was enhanced on nanoleaf surfaces compared with those on the other two surfaces.

Aniket et al. [158] investigated the effects of nanoscale roughness and the chemistry of bioactive silica-calciumphosphate nanocomposites (SCPC50) coated on Ti-6Al$4 \mathrm{~V}$ implants and proved that nanoscale surfaces lead to early osteoblast differentiation. Cell attachment was higher on SCPC50-coated substrates compared to the uncoated controls; however, cells on the uncoated substrate exhibited greater spreading and superior quality of F-actin filaments than cells on the SCPC50-coated substrates.

According to another study [159], differentiation is not the only variable to take into account, but the quality of mineralized tissue being developed is also important. Enhanced osteogenic cell differentiation on modified titanium is not a sufficient indicator of enhanced in vitro mineralization.

Some techniques allow for the correction of bone defects by grafting adult mesenchymal cells [160]. The use of nanofeatured surfaces, in association with these bone regeneration techniques, could allow for better new-bone formation and ultimately improve osseointegration and implant success.

2.13. Bacterial Adhesion. Unlike failure in reaching osseointegration, which involves very limited implants and arises within a short time $[161,162]$, peri-implant infections can occur a long time after implant placement. In this circumstance, in addition to implant failure there is also the prosthetic failure to be taken in consideration. Notwithstanding that some studies reported extremely high peri-implant infection rates, exceeding $80 \%$ of the implant population [163-178], recently those studies were questioned [179] and the estimate of real prevalence of the pathology was lowered. Those studies were biased indeed by several defects such as variety of definition of the pathology, discrepancy between the extremely high prevalence of the pathology and the still extremely high rate of success at long time, difficulty to obtain an exact diagnosis with clinical examination and $\mathrm{X}$-rays, and inability to compare different protocols [179]. Furthermore, it is not clear if the peri-implant infection is the primary cause of bone resorption or the result of different pathologic processes, like residual cement in peri-implant sulcus, mistakes in surgical protocol or prosthetic restoration, metabolic disease, and smoke habit. Thus, a realistic estimate of long-term prevalence of peri-implant infections is around $1-2 \%$ [179]. Currently, a frequent, professional plaque removal 
protocol is considered as an appropriate strategy for the prevention of peri-implant infections [180].

Consequently, research in antibacterial properties is not less promising than in enhancing osseointegration. Nanofeatured surfaces modified to reduce plaque build-up and the promotion of plaque removal may be an effective long-term strategy for reducing true peri-implant infections.

The relationship between these diseases and bacterial plaque accumulation is well established [181-195]. Bacterial adhesion occurs in four phases: transport of the bacterium to the surface, initial adhesion with a reversible and irreversible stage, attachment by specific interactions, and, finally, colonization to form a biofilm [196]. Following the primary attachment of single cells, bacteria start to colonize and grow on the implant surface developing multilayered cellular biofilms. These microbial communities are highly organized and structured. They are embedded in extracellular polymeric matrices that develop into maturation, achieving virulent and pathogenic features $[197,198]$.

Bacterial communities are important to note because they emphasize the ability of bacteria to self-organize and resist environmental perturbations since they are more effective cooperatively than in isolation and respond to environmental changes as a unit rather than as single entities [199].

It is postulated that biofilms contribute to antibiotic resistance by at least three mechanisms: reduced penetration of antibacterial drugs across the extracellular polymeric substance, a favorable environment within the inner layers, and bacterial cell differentiation and role specialization providing increased protection. These mechanisms permit the microbial community to resist antibiotic concentrations 1000 -fold higher than those necessary to eradicate planktonic populations [200, 201].

Differences in sulcus microbiota composition were observed between successful and compromised implants. From a high proportion of coccoid bacteria, with a low proportion of anaerobic and aerobic species, a small number of Gram-negative species, and low detection of periodontal pathogenic bacteria in healthy sites, the microbiota shifts to mainly Gram-negative anaerobic rods and spirochetes in diseased site [202-204]. Successful implants are colonized principally by oral streptococci, capnocytophagae, Veillonella parvula, Peptostreptococcus micros, and Fusobacterium nucleatum [197].

Communication among different species within biofilms appears to be the key process in explaining how plaque can act as a single unit, and how specific types of bacteria emerge and impair the balance within the host [205]. Bacteria tend to agglomerate in clusters according to their nutritional requirements $[197,206]$. The species within complexes are closely associated with each other and precise connections are also established between certain complexes. Bacteria belonging to green and yellow clusters are associated with healthy tissues, while the red and orange clusters are detected at pathological sites [205].

The bacterial plaque composition is affected by periodontal conditions: in partially edentulous patients, more motile rods and spirochetes were found $[197,207]$. In a clinical study comparing de novo plaque formation around implants and teeth, colonization by periodontal pathogens was observed two weeks after abutment connection in the peri-implant sulcus, and after three months, the microbiota was strikingly similar for the implants and teeth [207].

Ideally, to enhance the success of implants, their surfaces should inhibit bacterial colonization and concomitantly promote osteoblast function. Bacterial adhesion to biomaterials has previously been linked to factors such as the surface free energy [196, 208, 209], chemical composition, and physical characteristics of the surface including material surface irregularities and roughness [209-212]. Studies of bacterial colonization on nanostructured titanium surfaces demonstrated improved colonization efficiency when the surface roughness was increased [209, 213].

Since the size and rigidity of osteoblasts and bacteria are different, the idea of using surface topography to selectively control the response from osteoblasts and bacteria seems attractive. In principle, the surface topography could alter the response of bacteria and osteoblasts, since their rigidity and sizes are different [144]. Rough surfaces allow for increased biofilm formation compared to smoother implants [144, 196, 212, 214-216].

Puckett et al. have recently studied the correlation between bacterial adhesion and the spatial organization of nanofeatures of different shapes and sizes on $\mathrm{TiO}_{2}$ surfaces [209]. The study showed that nanorough titanium surface produced by electron beam evaporation allows the lower bacterial adhesion and nanotubular and nanotextured surfaces produced by two different anodization processes, on the contrary, enhance bacterial adhesion more than a conventional smooth surface. Therefore, it is reasonable to think that very rough surfaces, such as nanotubular ones, which allow a large osseointegration, also enable an enhanced bacterial growth. On the contrary, it was proven that reducing the roughness below to $0.2 \mu \mathrm{m}$ did not significantly influence the microbial composition (not adhesion) [212, 217, 218].

Smooth, turned (TU) titanium, nanoporous $\mathrm{TiO}_{2}$ coated (SG), and anodized $\mathrm{Ca}^{2+}$ modified (OC) surfaces have all been shown to be suitable not only for osseointegration but also for soft tissue healing [92, 219]. Titanium surfaces modified with ion implantation $(\mathrm{Ca}+, \mathrm{N}+$, and $\mathrm{F}+)$, oxidation (anode oxidation, titanium spraying), ion plating (TiN, alumina), and ion beam mixing ( $\mathrm{Ag}, \mathrm{Sn}, \mathrm{Zn}$, and $\mathrm{Pt}$ ) with $\mathrm{Ar}+$ were compared to polished titanium. F+-implanted specimens were significantly more effective in inhibiting the growth of both Porphyromonas gingivalis and Actinobacillus actinomycetemcomitans. Other surface-modified specimens showed comparable responses with polished titanium for adhesion and bacterial growth [208].

In an in vitro study, three surfaces (turned titanium (TU), nanoporous $\mathrm{TiO}_{2}$ coated (SG), and anodized $\mathrm{Ca}^{2+}$ modified (OC) surfaces) were evaluated for their ability to adhere bacterial colonies of Streptococcus sanguinis and Actinomyces naeslundii [220]. The presence of nanotopographic alterations of the implant surfaces did not cause significantly greater accumulations of bacteria compared to smooth surfaces. The OC surface has greater microtopographical structures than the others, although all three are classified as smooth (i.e., $\mathrm{Sa}<0.5 \mu \mathrm{m}$ ) [23]. In addition, at 
the OC surface, the bacterial biofilm volume was, to some extent, greater than the other two surfaces. The presence of saliva, with its own glycoproteins, increased 11-times the capacity of the tested bacteria needed to adhere. The complexity of the microbiotic ecosystem likely increases the bacterial capacity of adhesion to surfaces due to the possible intensive action among different bacterial species [221].

Titanium surfaces modified with poly(methacrylic acid) brushes and silk sericin have been shown to reduce the adhesion of $S$. aureus and $S$. epidermidis and also promote osteoblast adhesion, proliferation, and alkaline phosphatase (ALP) activity [222].

A recent study on $\mathrm{ZnO}$ and $\mathrm{TiO}_{2}$ nanoscale surfaces showed a reduction in the adhesion of $S$. epidermidis compared with microstructured surfaces. Moreover, increased osteoblast adhesion, ALP activity, and calcium mineral depositions were also observed [155]. Similarly, Colon et al. found that $S$. epidermidis adhesion on nanostructured $\mathrm{ZnO}$ and $\mathrm{TiO}_{2}$ was less than that observed on the microphase formulations [155]. Reduction of S. epidermidis adhesion to $80 \mathrm{~nm}$ nanotube surfaces was reported in other studies [223].

In recent experiments, biofilm development on newly designed laser-modified titanium implant surfaces was evaluated and compared with that of conventional sandblasted titanium used in implant dentistry. Results showed a significantly lower total volume of the biomass on laser-modified surfaces, while no significant changes in live/dead bacteria were noticed between materials [224].

Results contradicting these findings were reported by Singh et al. [225] in studies examining protein adsorption, bacterial adhesion, and biofilm formation on nanostructured titanium thin films with a root-mean-square surface roughness $(\mathrm{Rq})$ ranging from 16 to $32 \mathrm{~nm}$. The increase in surface roughness presented a positive correlation with protein absorption and was inversely proportional to bacterial adhesion and biofilm formation. As a possible explanation of these findings, it was postulated that the rougher surfaces may increase the amount of adsorbed proteins, passivating the surfaces and inhibiting cell attachment. This would imply that the mechanisms underlying protein adhesion enhancement are more complex than a simple geometrical amplification of increased available surface being due to increased surface roughness.

Lin et al. [226] examined the bacterial adhesion and biofilm formation on quaternized chitosan-loaded titanium nanotubes of $200 \mathrm{~nm}$ length and various diameters $(80,120$, 160 , and $200 \mathrm{~nm}$ ). Chitosan, and in particular quaternized chitosan, has been unequivocally proven to be inherently antibacterial, due to its chemical structure (cationic nature) [227-229].

The authors found that quaternized chitosan-loaded surfaces can significantly inhibit bacterial adhesion and biofilm formation compared with smooth surfaces. A major limitation in this study is the remarkable solubility of quaternized chitosan, in that more than half of the initially loaded quaternized chitosan dose was released within five days, while antibacterial activity should be extended over several years to be clinically effective.
A silver-modified surface and a silanized titanium nanofeatured surface were evaluated in a dog model of experimental peri-implantitis induced by ligature placement. The two surfaces showed a superior response with regard to bacterial accumulation compared with traditional titanium surfaces [67].

\section{Regulatory and Safety Issues}

A large variety of products obtained through nanotechnology, including more than 50 medicinal agents of pharmaceuticals, diagnostics, and biomaterials, have already been approved by regulatory authorities for clinical use. This indicates that a consolidated regulatory framework is applicable for assessing the biological and clinical profiles of these agents, as well as their safety and biocompatibility.

Current regulation of nanomedicines, including medical devices, is essentially based on criteria and study design requirements similar to those used for conventional materials. According to these regulatory bodies, there is no need for a new set of guidelines specific to nanomedicines. If research identifies toxicological risks that are unique to nanomaterials, however, additional studies and applications of ad hoc methods may become necessary. In addition, a risk-management system should be implemented, including risk minimization and postmarketing surveillance programs. These should become mandatory requirements for all kinds of medical applications using nanotechnology [230].

The regulatory status of titanium implants falls within the borderline of tools for regenerative medicine and medical devices, especially those devices used for materials in which a nanoscale surface coating is incorporated to promote bone growth and osseointegration. Currently, there are several knowledge gaps regarding the long-term effects of nanoscale titanium implants and uncertainties on how the safety characteristics of these implants should be evaluated.

3.1. Toxic Effects of Titanium-Based Nanomaterials. Several studies have indicated that titanium dioxide nanoparticles, when absorbed in the body, can interact with cell constituents in a manner different than conventional molecules [231]. These nanoparticles were proven to possess pronounced surface reactivities and unique modes of action in biological systems, due to their propensity to generate free radicals and induce oxidative stress. Consequently, a range of cellular and molecular modifications may develop, including proinflammatory gene activation, apoptotic changes, genotoxicity, abnormalities in cell adhesion and migration processes, cell proliferation, immunogenic effects, and prothrombotic effects.

Pure titanium and titanium alloys have inherent corrosion resistance, and they are considered nontoxic. However, limited information exists on the corrosion characteristics of nanoscale titanium implants. There is some evidence indicating that metallic implants may undergo surface degradation and may become the site of reactions that lead to the release of metal ions to surrounding tissues. This process may cause peri-implant inflammatory reactions and cytotoxicity $[232,233]$. It has been suggested that a combined action of 
oxidative stress and "foreign-body" phenomena associated with the release of titanium nanoparticles from surface coatings may induce host immune responses, autophagic changes, and lysosomal dysfunction [234, 235]. Furthermore, high concentrations of titanium dioxide nanoparticles have been shown to cause dose-dependent proinflammatory effects on human gingival fibroblasts [236]. Internalization of titanium dioxide nanoparticles associated with cellular changes has been observed in studies on human osteoblast cells [237].

Systemic effects manifested as cardiac alterations have recently been described in rats treated with nanotitanium [238]. Certainly, the clinical relevance of the toxicological data is still to be demonstrated. Most observations come from studies using cell cultures or from in vivo assays with laboratory animals exposed to extremely high doses of titanium dioxide nanoparticles by oral gavage or inhalation [231]. Furthermore, most experiments on the potential of nanotitanium to induce toxicity have addressed specific situations unrelated to dental implantology, for example, risks associated with the pulmonary absorption of titanium nanoparticles in occupational settings or the dermal application of sunscreens containing nanotitanium. This is a relevant point since the toxic reaction occurring at the material-tissue interface is a function of the specific tissue where the interface is created.

Isolated reports of allergic reactions to titanium dental implants have been published [239]. Based on current knowledge, however, there is no scientific evidence of nanodependent toxicity occurring in humans after the application of titanium implants.

3.2. Safety Testing. In a recent monograph [240] $\mathrm{TiO} 2$ is referred to be possibly carcinogenic to humans based on sufficient evidence in animal model and insufficient evidence in human model. However these considerations refer exclusively to titanium particles used as pigment. Dental implant is not nanoparticles inserted in human body; conversely it is a macroscopic titanium bulk with nanometric surfaces. Although it is possible that mechanical wear and/or surface corrosion produce solid particulate wear debris and soluble forms, this occurrence is reported only from the bearing site of orthopedic prosthesis $[63,241,242]$. There is no evidence of particulate release from dental implants, which by definition are immobile within the bone.

Because of the peculiar biological properties of titanium nanoparticles, it is not completely clear how experimental studies should be designed in order to assess the safety and biocompatibility of nanoscale implants. Regulatory documents on the assessment of the adverse effects of nanomaterials used in medical devices have recently been published $[243,244]$.

Biocompatibility testing standards exist that specifically cover dental materials, such as ISO 7405 and ISO 10993 [245]. Several types of short-term or long-term tests, including cell culture assays, in vivo studies in animals, implantation tests, and clinical trials, have been proposed to assess the safety and biocompatibility of new dental materials.

Current evidence suggests that the biological response to dental implants may vary depending on the device category, the tissue contact location, and the contact time. Implantation assays in which the test material remains in place for 1-2 years before being examined have been proposed to assess the possible long-term effects of permanent implants such as chronic inflammation, propensity of infection, blood interaction, fibrogenic cell function, and oncogenicity [245247]. It is not clear if these evaluation methods may be suitable for assessing the biocompatibility of nanoenabled dental implants.

\section{Conclusions}

Nanotechnology can lead to significant changes in the physicochemical and topographical characteristics of titanium surfaces by influencing the surface free energy, wettability, and absorption of proteins. Different technologies have been developed to control the surface characteristics of titanium at nanometric levels. The validity of these methods is not easily comparable because of the great discrepancies in processes and mechanisms implicated in the surface modifications. Biological molecules, ions, and cells can interact with these nanomodified surfaces by complex mechanisms and can affect the osseointegration process in different ways. Nanoscale surface modifications can increase the affinity to the bone at the bone-implant interface by promoting bone formation and enhancing BIC. Studies on cell cultures have identified nanoscale topographical features that promote adhesion and bone induction in osteoprogenitor cells. Titanium nanomaterials possessing such characteristics could represent a valuable tool for increasing osseointegration, particularly in patients considered at risk for bone qualitative deficits. Some modified surfaces with nanoscale features are already available, namely, those modified with hydrofluoric acid or with calcium phosphate.

The application of nanotechnology to implant surfaces may significantly contribute to the prevention of peri-implant infections. Studies have demonstrated that surface characteristics can influence the adhesion and growth of the bacterial microflora, and convincing experimental evidence is currently available suggesting that nanometric changes can modulate these properties. In perspective, the introduction of nanoenabled implant surfaces can be expected to exert a positive influence in implantology, by improving osseointegration and reducing peri-implant infection rates.

Although the advantages associated with the use of nanoscale titanium are supported by a large body of experimental observations, the potential risks and risk-benefit balance of nanotitanium have yet to be evaluated, especially in long-term studies. The development of new test methods is needed to assess the modes of action, biocompatibility, and long-term effects possibly associated with prolonged tissue contact of nanoscale titanium implants. Research priorities should also include detailed studies to demonstrate the superiority and real clinical advantages of nanoscale titanium as a cost-effective tool compared with traditional materials.

\section{Conflicts of Interest}

The authors declare that they have no conflicts of interest. 


\section{References}

[1] T. Albrektsson, P. I. Branemark, H. A. Hansson, and J. Lindstrom, "Osseointegrated titanium implants. Requirements for ensuring a long-lasting, direct bone-to-implant anchorage in man," Acta Orthopaedica Scandinavica, vol. 52, no. 2, pp. 155170, 1981.

[2] P. I. Branemark, R. Adell, U. Breine, B. O. Hansson, J. Lindstrom, and A. Ohlsson, "Intra-osseous anchorage of dental prostheses. I. Experimental studies," Scandinavian Journal of Plastic and Reconstructive Surgery, vol. 3, no. 2, pp. 81-100, 1969.

[3] L. Linder, T. Albrektsson, P. I. Branemark et al., "Electron microscopic analysis of the bone-titanium interface," Acta Orthopaedica Scandinavica, vol. 54, no. 1, pp. 45-52, 1983.

[4] G. A. Zarb and A. Schmitt, "The longitudinal clinical effectiveness of osseointegrated dental implants: The Toronto study. Part III: Problems and complications encountered," The Journal of Prosthetic Dentistry, vol. 64, no. 2, pp. 185-194, 1990.

[5] R. Adell, U. Lekholm, B. Rockler, and P. I. Branemark, "A 15year study of osseointegrated implants in the treatment of the edentulous jaw," International Journal of Oral Surgery, vol. 10, no. 6, pp. 387-416, 1981.

[6] R. A. Jaffin and C. L. Berman, "The excessive loss of Branemark fixtures in type IV bone: a 5-year analysis., Journal of Periodontology, vol. 62, no. 1, pp. 2-4, 1991.

[7] C. A. Bain, "Smoking and implant failure-benefits of a smoking cessation protocol," International Journal of Oral and Maxillofacial Implants, vol. 11, no. 6, pp. 756-759, 1996.

[8] J. P. Fiorellini, P. K. Chen, M. Nevins, and M. L. Nevins, "A Retrospective Study of Dental Implants in Diabetic Patients," International Journal of Periodontics and Restorative Dentistry, vol. 20, no. 4, pp. 367-373, 2000.

[9] R. R. Baena, R. Pastorino, E. F. Gherlone, L. Perillo, S. M. Lupi, and A. Lucchese, "Histomorphometric evaluation of two different bone substitutes in sinus augmentation procedures: a randomized controlled trial in humans," Int J Oral Maxillofac Implants, 2016.

[10] Y. B. RR, S. M. Lupi, R. Pastorino, C. Maiorana, A. Lucchese, and S. Rizzo, "Radiographic evaluation of regenerated bone following poly(lactic-co-glycolic) acid/hydroxyapatite and deproteinized bovine bone graft in sinus lifting," The Journal of Craniofacial Surgery, vol. 24, no. 3, pp. 845-848, 2013.

[11] B. Kasemo, "Biocompatibility of titanium implants: surface science aspects," The Journal of Prosthetic Dentistry, vol. 49, no. 6, pp. 832-837, 1983.

[12] C. B. Johansson and T. Albrektsson, "A removal torque and histomorphometric study of commercially pure niobium and titanium implants in rabbit bone," Clinical Oral Implants Research, vol. 2, no. 1, pp. 24-29, 1991.

[13] F. Suska, C. Gretzer, M. Esposito et al., "In vivo cytokine secretion and NF- $\kappa \mathrm{B}$ activation around titanium and copper implants," Biomaterials, vol. 26, no. 5, pp. 519-527, 2005.

[14] R. Smeets, B. Stadlinger, F. Schwarz et al., "Impact of dental implant surface modifications on osseointegration," BioMed Research International, vol. 2016, Article ID 6285620, 16 pages, 2016.

[15] L. F. Cooper, "Biologic determinants of bone formation for osseointegration: clues for future clinical improvements," The Journal of Prosthetic Dentistry, vol. 80, no. 4, pp. 439-449, 1998.

[16] L. Le Guehennec, A. Soueidan, P. Layrolle, and Y. Amouriq, "Surface treatments of titanium dental implants for rapid osseointegration," Dental Materials, vol. 23, no. 7, pp. 844-854, 2007.

[17] A. Nanci, J. D. Wuest, L. Peru et al., "Chemical modification of titanium surfaces for covalent attachment of biological molecules," Journal of Biomedical Materials Research, vol. 40, no. 2, pp. 324-335, 1998.

[18] B. D. Boyan, Z. Schwartz, and J. C. Hambleton, "Response of bone and cartilage cells to biomaterials in vivo and in vitro," The Journal of Oral Implantology, vol. 19, no. 2, pp. 116-122, 1993.

[19] Z. Schwartz, L. D. Swain, T. Marshall et al., "Modulation of matrix vesicle enzyme activity and phosphatidylserine content by ceramic implant materials during endosteal bone healing," Calcified Tissue International, vol. 51, no. 6, pp. 429-437, 1992.

[20] D. Zaffe, Y. B. R. Rodriguez, S. Rizzo et al., "Behavior of the bone-titanium interface after push-in testing: a morphological study," Journal of Biomedical Materials Research Part A, vol. 64, no. 2, pp. 365-371, 2003.

[21] D. Buser, R. K. Schenk, S. Steinemann, J. P. Fiorellini, C. H. Fox, and H. Stich, "Influence of surface characteristics on bone integration of titanium implants. a histomorphometric study in miniature pigs," Journal of Biomedical Materials Research, vol. 25, no. 7, pp. 889-902, 1991.

[22] S. Hansson and M. Norton, "The relation between surface roughness and interfacial shear strength for bone-anchored implants. A mathematical model," Journal of Biomechanics, vol. 32, no. 8, pp. 829-836, 1999.

[23] T. Albrektsson and A. Wennerberg, "Oral implant surfaces: part 1-review focusing on topographic and chemical properties of different surfaces and in vivo responses to them," The International Journal of Prosthodontics, vol. 17, no. 5, pp. 536543, 2004.

[24] T. Albrektsson and A. Wennerberg, "Oral implant surfaces: part 2-review focusing on clinical knowledge of different surfaces," The International Journal of Prosthodontics, vol. 17, no. 5, pp. 544-564, 2004.

[25] M. Wong, J. Eulenberger, R. Schenk, and E. Hunziker, "Effect of surface topology on the osseointegration of implant materials in trabecular bone," Journal of Biomedical Materials Research, vol. 29, no. 12, pp. 1567-1575, 1995.

[26] A. Wennerberg, A. Ektessabi, T. Albrektsson, C. Johansson, and B. Andersson, "A 1-year follow-up of implants of differing surface roughness placed in rabbit bone," The International Journal of Oral \& Maxillofacial Implants, vol. 12, no. 4, pp. 486494, 1997.

[27] J. E. Davies, "Understanding peri-implant endosseous healing," Journal of Dental Education, vol. 67, no. 8, pp. 932-949, 2003.

[28] J. Y. Park, C. H. Gemmell, and J. E. Davies, "Platelet interactions with titanium: modulation of platelet activity by surface topography," Biomaterials, vol. 22, no. 19, pp. 2671-2682, 2001.

[29] G. B. Schneider, H. Perinpanayagam, M. Clegg et al., "Implant surface roughness affects osteoblast gene expression," Journal of Dental Research, vol. 82, no. 5, pp. 372-376, 2003.

[30] Z. M. Isa, G. B. Schneider, R. Zaharias, D. Seabold, and C. M. Stanford, "Effects of fluoride-modified titanium surfaces on osteoblast proliferation and gene expression," International Journal of Oral and Maxillofacial Implants, vol. 21, no. 2, pp. 203211, 2006.

[31] T. Ogawa and I. Nishimura, "Different bone integration profiles of turned and acid-etched implants associated with modulated expression of extracellular matrix genes," Int J Oral Maxillofac Implants, vol. 18, no. 2, pp. 200-210, 2003. 
[32] T. Ogawa and I. Nishimura, "Genes differentially expressed in titanium implant healing," Journal of Dental Research, vol. 85, no. 6, pp. 566-570, 2006.

[33] A. Abron, M. Hopfensperger, J. Thompson, and L. F. Cooper, "Evaluation of a predictive model for implant surface topography effects on early osseointegration in the rat tibia model," Journal of Prosthetic Dentistry, vol. 85, no. 1, pp. 40-46, 2001.

[34] D. Buser, N. Broggini, M. Wieland et al., "Enhanced bone apposition to a chemically modified SLA titanium surface," Journal of Dental Research, vol. 83, no. 7, pp. 529-533, 2004.

[35] J. E. Ellingsen, C. B. Johansson, A. Wennerberg, and A. Holmen, "Improved retention and bone-tolmplant contact with fluoridemodified titanium implants," Int J Oral Maxillofac Implants, vol. 19, no. 5, pp. 659-666, 2004.

[36] L. G. Gutwein and T. J. Webster, "Increased viable osteoblast density in the presence of nanophase compared to conventional alumina and titania particles," Biomaterials, vol. 25, no. 18, pp. 4175-4183, 2004.

[37] S.-H. Oh, R. R. Finõnes, C. Daraio, L.-H. Chen, and S. Jin, "Growth of nano-scale hydroxyapatite using chemically treated titanium oxide nanotubes," Biomaterials, vol. 26, no. 24, pp. 4938-4943, 2005.

[38] R. L. Price, L. G. Gutwein, L. Kaledin, F. Tepper, and T. J. Webster, "Osteoblast function on nanophase alumina materials: Influence of chemistry, phase, and topography," Journal of Biomedical Materials Research - Part A, vol. 67, no. 4, pp. 12841293, 2003.

[39] T. J. Webster, C. Ergun, R. H. Doremus, R. W. Siegel, and R. Bizios, "Enhanced functions of osteoblasts on nanophase ceramics," Biomaterials, vol. 21, no. 17, pp. 1803-1810, 2000.

[40] T. J. Webster and J. U. Ejiofor, "Increased osteoblast adhesion on nanophase metals: Ti, Ti6Al4V, and CoCrMo," Biomaterials, vol. 25, no. 19, pp. 4731-4739, 2004.

[41] Z. Schwartz, E. Nasazky, and B. D. Boyan, "Surface microtopography regulates osteointegration: the role of implant surface microtopography in osteointegration," Alpha Omegan, vol. 98, no. 2, pp. 9-19, 2005.

[42] L. E. Dike, C. S. Chen, M. Mrksich, J. Tien, G. M. Whitesides, and D. E. Ingber, "Geometric control of switching between growth, apoptosis, and differentiation during angiogenesis using micropatterned substrates," In Vitro Cellular and Developmental Biology - Animal, vol. 35, no. 8, pp. 441-448, 1999.

[43] A. J. Garcia and C. D. Reyes, "Bio-adhesive surfaces to promote osteoblast differentiation and bone formation," Journal of Dental Research, vol. 84, no. 5, pp. 407-413, 2005.

[44] P. Trisi, R. Lazzara, A. Rebaudi, W. Rao, T. Testori, and S. S. Porter, "Bone-implant contact on machined and dual acidetched surfaces after 2 months of healing in the human maxilla," Journal of Periodontology, vol. 74, no. 7, pp. 945-956, 2003.

[45] H. Schliephake, A. Aref, D. Scharnweber, S. Bierbaum, S. Roessler, and A. Sewing, "Effect of immobilized bone morphogenic protein 2 coating of titanium implants on periimplant bone formation," Clinical Oral Implants Research, vol. 16, no. 5, pp. 563-569, 2005.

[46] J. Becker, A. Kirsch, F. Schwarz et al., "Bone apposition to titanium implants biocoated with recombinant human bone morphogenetic protein-2 (rhBMP-2). A pilot study in dogs," Clinical Oral Investigations, vol. 10, no. 3, pp. 217-224, 2006.

[47] G. Mendonca, D. B. Mendonca, F. J. Aragao, and L. F. Cooper, "Advancing dental implant surface technology-from micronto nanotopography," Biomaterials, vol. 29, no. 28, pp. 3822-3835, 2008.
[48] A. Wennerberg and T. Albrektsson, "On implant surfaces: a review of current knowledge and opinions," The International Journal of Oral \& Maxillofacial Implants, vol. 25, no. 1, pp. 6374, 2010.

[49] L. X. Kong, Z. Peng, S.-D. Li, and P. M. Bartold, "Nanotechnology and its role in the management of periodontal diseases," Periodontology 2000, vol. 40, no. 1, pp. 184-196, 2006.

[50] E. M. Christenson, K. S. Anseth, J. J. van den Beucken et al., "Nanobiomaterial applications in orthopedics," Journal of Orthopaedic Research, vol. 25, no. 1, pp. 11-22, 2007.

[51] H. Liu, E. B. Slamovich, and T. J. Webster, "Increased osteoblast functions among nanophase titania/poly(lactide-co-glycolide) composites of the highest nanometer surface roughness," Journal of Biomedical Materials Research Part A, vol. 78, no. 4, pp. 798-807, 2006.

[52] T. Sjostrom, A. S. Brydone, R. D. Meek, M. J. Dalby, B. Su, and L. E. Mcnamara, "Titanium nanofeaturing for enhanced bioactivity of implanted orthopedic and dental devices," Nanomedicine (Lond), vol. 8, no. 1, pp. 89-104, 2013.

[53] F. Variola, J. B. Brunski, G. Orsini, P. T. de Oliveira, R. Wazen, and A. Nanci, "Nanoscale surface modifications of medically relevant metals: state-of-the art and perspectives," Nanoscale, vol. 3, no. 2, pp. 335-353, 2011.

[54] C. Marin, R. Granato, M. Suzuki, J. N. Gil, A. Piattelli, and P. G. Coelho, "Removal torque and histomorphometric evaluation of bioceramic grit-blasted/acid-etched and dual acid-etched implant surfaces: an experimental study in dogs," Journal of Periodontology, vol. 79, no. 10, pp. 1942-1949, 2008.

[55] J. A. Shibli, S. Grassi, A. Piattelli et al., "Histomorphometric evaluation of bioceramic molecular impregnated and dual acid-etched implant surfaces in the human posterior maxilla," Clinical Implant Dentistry and Related Research, vol. 12, no. 4, pp. 281-288, 2010.

[56] C. Aparicio, F. J. Gil, C. Fonseca, M. Barbosa, and J. A. Planell, "Corrosion behaviour of commercially pure titanium shot blasted with different materials and sizes of shot particles for dental implant applications," Biomaterials, vol. 24, no. 2, pp. 263-273, 2003.

[57] B. W. Darvell, N. Samman, W. K. Luk, R. K. F. Clark, and H. Tideman, "Contamination of titanium castings by aluminium oxide blasting," Journal of Dentistry, vol. 23, no. 5, pp. 319-322, 1995.

[58] H. E. Placko, S. Mishra, J. J. Weimer, and L. C. Lucas, "Surface characterization of titanium-based implant materials," International Journal of Oral and Maxillofacial Implants, vol. 15, no. 3, pp. 355-363, 2000.

[59] K. Mustafa, A. Wennerberg, J. Wroblewski, K. Hultenby, B. S. Lopez, and K. Arvidson, "Determining optimal surface roughness of $\mathrm{TiO}_{2}$ blasted titanium implant material for attachment, proliferation and differentiation of cells derived from human mandibular alveolar bone," Clinical Oral Implants Research, vol. 12 , no. 5, pp. 515-525, 2001.

[60] C. J. Ivanoff, C. Hallgren, G. Widmark, L. Sennerby, and A. Wennerberg, "Histologic evaluation of the bone integration of $\mathrm{TiO}_{2}$ blasted and turned titanium microimplants in humans," Clinical Oral Implants Research, vol. 12, no. 2, pp. 128-134, 2001.

[61] C. Yao, E. B. Slamovich, and T. J. Webster, "Enhanced osteoblast functions on anodized titanium with nanotube-like structures," Journal of Biomedical Materials Research Part A, vol. 85, no. 1, pp. 157-166, 2008.

[62] S. Oh, K. S. Brammer, Y. S. J. Li et al., "Stem cell fate dictated solely by altered nanotube dimension," Proceedings of 
the National Academy of Sciences of the United States of America, vol. 106, no. 7, pp. 2130-2135, 2009.

[63] M. Kulkarni, A. Mazare, E. Gongadze et al., "Titanium nanostructures for biomedical applications," Nanotechnology, vol. 26, no. 6, Article ID 062002, 2015.

[64] K. S. Brammer, S. Oh, C. J. Cobb, L. M. Bjursten, H. van der Heyde, and S. Jin, "Improved bone-forming functionality on diameter-controlled $\mathrm{TiO}_{2}$ nanotube surface," Acta Biomaterialia, vol. 5, no. 8, pp. 3215-3223, 2009.

[65] C. von Wilmowsky, S. Bauer, S. Roedl, F. W. Neukam, P. Schmuki, and K. A. Schlegel, "The diameter of anodic $\mathrm{TiO}_{2}$ nanotubes affects bone formation and correlates with the bone morphogenetic protein-2 expression in vivo," Clinical Oral Implants Research, vol. 23, no. 3, pp. 359-366, 2012.

[66] C. von Wilmowsky, S. Bauer, R. Lutz et al., "In vivo evaluation of anodic $\mathrm{TiO}_{2}$ nanotubes; an experimental study in the pig," Journal of Biomedical Materials Research Part B: Applied Biomaterials, vol. 89, no. 1, pp. 165-171, 2009.

[67] M. Godoy-Gallardo, M. C. Manzanares-Cespedes, P. Sevilla et al., "Evaluation of bone loss in antibacterial coated dental implants: An experimental study in dogs," Materials Science \& Engineering C: Materials for Biological Applications, vol. 69, pp. 538-545, 2016.

[68] Y. Gao, Y. Li, J. Xiao, L. Xu, K. Hu, and L. Kong, "Effects of microrough and hierarchical hybrid micro/nanorough surface implants on osseointegration in ovariectomized rats: A longitudinal in vivo microcomputed tomography evaluation," Journal of Biomedical Materials Research - Part A, vol. 100, no. 8, pp. 2159-2167, 2012.

[69] K. S. Brammer, C. J. Frandsen, and S. Jin, “ $\mathrm{TiO}_{2}$ nanotubes for bone regeneration," Trends in Biotechnology, vol. 30, no. 6, pp. 315-322, 2012.

[70] F. Vetrone, F. Variola, P. T. De Oliveira et al., "Nanoscale oxidative patterning of metallic surfaces to modulate cell activity and fate," Nano Letters, vol. 9, no. 2, pp. 659-665, 2009.

[71] X. X. Wang, S. Hayakawa, K. Tsuru, and A. Osaka, "Bioactive titania gel layers formed by chemical treatment of Ti substrate with a $\mathrm{H}_{2} \mathrm{O}_{2} / \mathrm{HCl}$ solution," Biomaterials, vol. 23, no. 5, pp. 13531357, 2002.

[72] F. K. Mante, K. Little, M. O. Mante, C. Rawle, and G. R. Baran, "Oxidation of titanium, RGD peptide attachment, and matrix mineralization rat bone marrow stromal cells.", The Journal of oral implantology, vol. 30, no. 6, pp. 343-349, 2004.

[73] L. F. Cooper, Y. Zhou, J. Takebe et al., "Fluoride modification effects on osteoblast behavior and bone formation at $\mathrm{TiO}_{2}$ gritblasted c.p. titanium endosseous implants," Biomaterials, vol. 27, no. 6, pp. 926-936, 2006.

[74] T. Berglundh, I. Abrahamsson, J. P. Albouy, and J. Lindhe, "Bone healing at implants with a fluoride-modified surface: an experimental study in dogs," Clinical Oral Implants Research, vol. 18, no. 2, pp. 147-152, 2007.

[75] M. G. Tavares, P. T. de Oliveira, A. Nanci, A. C. Hawthorne, A. L. Rosa, and S. P. Xavier, "Treatment of a commercial, machined surface titanium implant with $\mathrm{H}_{2} \mathrm{SO}_{4} / \mathrm{H}_{2} \mathrm{O}_{2}$ enhances contact osteogenesis," Clinical Oral Implants Research, vol. 18, no. 4, pp. 452-458, 2007.

[76] X. X. Wang, S. Hayakawa, K. Tsuru, and A. Osaka, "A comparative study of in vitro apatite deposition on heat-, $\mathrm{H}(2) \mathrm{O}(2)$-, and $\mathrm{NaOH}$-treated titanium surfaces," J Biomed Mater Res, vol. 54, no. 2, pp. 172-178, 2001.
[77] M. Uchida, H. M. Kim, F. Miyaji, T. Kokubo, and T. Nakamura, "Apatite formation on zirconium metal treated with aqueous NaOH," Biomaterials, vol. 23, no. 1, pp. 313-317, 2002.

[78] H. M. Kim, T. Kokubo, S. Fujibayashi, S. Nishiguchi, and T. Nakamura, "Bioactive macroporous titanium surface layer on titanium substrate," Journal of Biomedical Materials Research, vol. 52, no. 3, pp. 553-557, 2000.

[79] N. Tsukimura, T. Ueno, F. Iwasa et al., "Bone integration capability of alkali- and heat-treated nanobimorphic Ti-15Mo5Zr-3Al," Acta Biomaterialia, vol. 7, no. 12, pp. 4267-4277, 2011.

[80] D. K. Pattanayak, T. Kawai, T. Matsushita, H. Takadama, T. Nakamura, and T. Kokubo, "Effect of $\mathrm{HCl}$ concentrations on apatite-forming ability of $\mathrm{NaOH}-\mathrm{HCl}$ - and heat-treated titanium metal," Journal of Materials Science: Materials in Medicine, vol. 20, no. 12, pp. 2401-2411, 2009.

[81] D. K. Pattanayak, S. Yamaguchi, T. Matsushita, and T. Kokubo, "Effect of heat treatments on apatite-forming ability of $\mathrm{NaOH}$ and HCl-treated titanium metal," Journal of Materials Science: Materials in Medicine, vol. 22, no. 2, pp. 273-278, 2011.

[82] H. W. Kim, Y. H. Koh, L. H. Li, S. Lee, and H. E. Kim, "Hydroxyapatite coating on titanium substrate with titania buffer layer processed by sol-gel method," Biomaterials, vol. 25, no. 13, pp. 2533-2538, 2004.

[83] C. S. Chai, K. A. Gross, and B. Ben-Nissan, "Critical ageing of hydroxyapatite sol-gel solutions," Biomaterials, vol. 19, no. 24, pp. 2291-2296, 1998.

[84] D. B. Haddow, P. F. James, and R. Van Noort, "Sol-Gel Derived Calcium Phosphate Coatings for Biomedical Applications," Journal of Sol-Gel Science and Technology, vol. 13, no. 1-3, pp. 261-265, 1999.

[85] L.-D. Piveteau, B. Gasser, and L. Schlapbach, "Evaluating mechanical adhesion of sol-gel titanium dioxide coatings containing calcium phosphate for metal implant application," Biomaterials, vol. 21, no. 21, pp. 2193-2201, 2000.

[86] K. Cheng, W. Weng, H. Qu et al., "Sol-gel preparation andin vitro test of fluorapatite/hydroxyapatite films," Journal of Biomedical Materials Research, vol. 69, no. 1, pp. 33-37, 2004.

[87] C. J. Tredwin, A. M. Young, E. A. Abou Neel, G. Georgiou, and J. C. Knowles, "Hydroxyapatite, fluor-hydroxyapatite and fluorapatite produced via the sol-gel method: Dissolution behaviour and biological properties after crystallisation," Journal of Materials Science: Materials in Medicine, vol. 25, no. 1, pp. 47-53, 2014.

[88] B. Ben-Nissan and A. H. Choi, "Sol-gel production of bioactive nanocoatings for medical applications. Part 1: An introduction," Nanomedicine, vol. 1, no. 3, pp. 311-319, 2006.

[89] S. Areva, H. Paldan, T. Peltola, T. Narhi, M. Jokinen, and M. Linden, "Use of sol-gel-derived titania coating for direct soft tissue attachment," Journal of Biomedical Materials Research Part A, vol. 70, no. 2, pp. 169-178, 2004.

[90] H. Paldan, S. Areva, T. Tirri et al., "Soft tissue attachment on sol-gel-treated titanium implants in vivo," Journal of Materials Science: Materials in Medicine, vol. 19, no. 3, pp. 1283-1290, 2008.

[91] S. Rossi, T. Tirri, H. Paldan, H. Kuntsi-Vaattovaara, R. Tulamo, and T. Närhi, "Peri-implant tissue response to $\mathrm{TiO} 2$ surface modified implants," Clinical Oral Implants Research, vol. 19, no. 4, pp. 348-355, 2008.

[92] A. Wennerberg, V. Frojd, M. Olsson et al., "Nanoporous $\mathrm{TiO}_{2}$ thin film on titanium oral implants for enhanced human soft tissue adhesion: A light and electron microscopy study," Clinical Implant Dentistry and Related Research, vol. 13, no. 3, pp. 184196, 2011. 
[93] D. Bollati, M. Morra, C. Cassinelli, S. M. Lupi, and Y. B. R. Rodriguez, "In vitro cytokine expression and in vivo healing and inflammatory response to a collagen-coated synthetic bone filler," BioMed Research International, vol. 2016, Article ID 6427681, 10 pages, 2016.

[94] C. A. Scotchford, C. P. Gilmore, E. Cooper, G. J. Leggett, and S. Downes, "Protein adsorption and human osteoblast-like cell attachment and growth on alkylthiol on gold self-assembled monolayers," Journal of Biomedical Materials Research, vol. 59, no. 1, pp. 84-99, 2002.

[95] Y. Germanier, S. Tosatti, N. Broggini, M. Textor, and D. Buser, "Enhanced bone apposition around biofunctionalized sandblasted and acid-etched titanium implant surfaces: a histomorphometric study in miniature pigs," Clinical Oral Implants Research, vol. 17, no. 3, pp. 251-257, 2006.

[96] M. L. Thorpe, “Thermal spray : Industry in transition," in Advanced Materials and Processes; (United States, pp., Medium, X; Size, pp. 50-61, Thermal spray, Industry in transition, 1993.

[97] J. C. Knowles, K. Gross, C. C. Berndt, and W. Bonfield, "Structural changes of thermally sprayed hydroxyapatite investigated by Rietveld analysis," Biomaterials, vol. 17, no. 6, pp. 639-645, 1996.

[98] W. R. Lacefield, "Current Status of Ceramic Coatings for Dental Implants," Implant Dentistry, vol. 7, no. 4, pp. 315-322, 1998.

[99] P. Cheang and K. A. Khor, "Addressing processing problems associated with plasma spraying of hydroxyapatite coatings," Biomaterials, vol. 17, no. 5, pp. 537-544, 1996.

[100] H. Caulier, S. Vercaigne, I. Naert et al., "The effect of Ca$\mathrm{P}$ plasma-sprayed coatings on the initial bone healing of oral implants: An experimental study in the goat," Journal of Biomedical Materials Research, vol. 34, no. 1, pp. 121-128, 1997.

[101] S. D. Cook, S. L. Salkeld, D. M. Gaisser, and W. R. Wagner, "The effect of surface macrotexture on the mechanical and histologic characteristics of hydroxylapatite-coated dental implants." The Journal of oral implantology, vol. 19, no. 4, pp. 288-294, 1993.

[102] J. E. Hulshoff and J. A. Jansen, "Initial interfacial healing events around calcium phosphate (Ca-P) coated oral implants," Clinical Oral Implant Research, vol. 8, no. 5, pp. 393-400, 1997.

[103] J. A. Jansen, J. P. van der Waerden, and J. G. Wolke, "Histologic investigation of the biologic behavior of different hydroxyapatite plasma-sprayed coatings in rabbits," Journal of Biomedical Materials Research, vol. 27, no. 5, pp. 603-610, 1993.

[104] K. A. Gross and C. C. Berndt, "Thermal processing of hydroxyapatite for coating production," Journal of Biomedical Materials Research, vol. 39, no. 4, pp. 580-587, 1998.

[105] J. L. Ong and D. C. Chan, "Hydroxyapatite and their use as coatings in dental implants: a review," Critical Reviews in Biomedical Engineering, vol. 28, no. 5-6, pp. 667-707, 2000.

[106] H. Zeng and W. R. Lacefield, "XPS, EDX and FTIR analysis of pulsed laser deposited calcium phosphate bioceramic coatings: The effects of various process parameters," Biomaterials, vol. 21, no. 1, pp. 23-30, 2000.

[107] Z. Zyman, J. Weng, X. Liu, X. Li, and X. Zhang, "Phase and structural changes in hydroxyapatite coatings under heat treatment," Biomaterials, vol. 15, no. 2, pp. 151-155, 1994.

[108] J. D. Haman, L. C. Lucas, and D. Crawmer, "Characterization of high velocity oxy-fuel combustion sprayed hydroxyapatite," Biomaterials, vol. 16, no. 3, pp. 229-237, 1995.

[109] P. G. Coelho and M. Suzuki, "Evaluation of an IBAD thin-film process as an alternative method for surface incorporation of bioceramics on dental implants: a study in dogs," Journal of Applied Oral Science, vol. 13, no. 1, pp. 87-92, 2005.
[110] J. L. Arias, M. B. Mayor, J. Pou, Y. Leng, B. Leon, and M. PerezAmor, "Micro- and nano-testing of calcium phosphate coatings produced by pulsed laser deposition," Biomaterials, vol. 24, no. 20, pp. 3403-3408, 2003.

[111] S. Puckett, R. Pareta, and T. J. Webster, "Nano rough micron patterned titanium for directing osteoblast morphology and adhesion," International Journal of Nanomedicine, vol. 3, no. 2, pp. 229-241, 2008.

[112] R. Carbone, I. Marangi, A. Zanardi et al., "Biocompatibility of cluster-assembled nanostructured $\mathrm{TiO}_{2}$ with primary and cancer cells," Biomaterials, vol. 27, no. 17, pp. 3221-3229, 2006.

[113] M. Vercellino, G. Ceccarelli, F. Cristofaro et al., "Nanostructured $\mathrm{TiO}_{2}$ surfaces promote human bone marrow mesenchymal stem cells differentiation to osteoblasts," Nanomaterials, vol. 6, no. 7, article 124, 2016.

[114] G. Ceccarelli, R. Presta, L. Benedetti, M. G. Cusella De Angelis, S. M. Lupi, and R. Rodriguez y Baena, "Emerging Perspectives in Scaffold for Tissue Engineering in Oral Surgery," Stem Cells International, vol. 2017, pp. 1-11, 2017.

[115] V. C. Mendes, R. Moineddin, and J. E. Davies, "The effect of discrete calcium phosphate nanocrystals on bone-bonding to titanium surfaces," Biomaterials, vol. 28, no. 32, pp. 4748-4755, 2007.

[116] C. Vieu, F. Carcenac, A. Pépin et al., "Electron beam lithography: resolution limits and applications," Applied Surface Science, vol. 164, no. 1-4, pp. 111-117, 2000.

[117] M. J. Dalby, N. Gadegaard, R. Tare et al., "The control of human mesenchymal cell differentiation using nanoscale symmetry and disorder," Nature Materials, vol. 6, no. 12, pp. 997-1003, 2007.

[118] P. Hanarp, D. S. Sutherland, J. Gold, and B. Kasemo, "Control of nanoparticle film structure for colloidal lithography," Colloids and Surfaces A: Physicochemical and Engineering Aspects, vol. 214, no. 1-3, pp. 23-36, 2003.

[119] M. A. Wood, "Colloidal lithography and current fabrication techniques producing in-plane nanotopography for biological applications," Journal of the Royal Society Interface, vol. 4, no. 12, pp. 1-17, 2007.

[120] J. C. Hansen, J. Yul Lim, L.-C. Xu, C. A. Siedlecki, D. T. Mauger, and H. J. Donahue, "Effect of surface nanoscale topography on elastic modulus of individual osteoblastic cells as determined by atomic force microscopy," Journal of Biomechanics, vol. 40, no. 13, pp. 2865-2871, 2007.

[121] G. M. de Peppo, H. Agheli, C. Karlsson et al., "Osteogenic response of human mesenchymal stem cells to well-defined nanoscale topography in vitro," International Journal of Nanomedicine, vol. 9, no. 1, pp. 2499-2515, 2014.

[122] A. Ballo, H. Agheli, J. Lausmaa, P. Thomsen, and S. Petronis, "Nanostructured model implants for in vivo studies: influence of well-defined nanotopography on de novo bone formation on titanium implants," International Journal of Nanomedicine, vol. 6, pp. 3415-3428, 2011.

[123] D. Karazisis, A. M. Ballo, S. Petronis et al., "The role of welldefined nanotopography of titanium implants on osseointegration: Cellular and molecular events in vivo," International Journal of Nanomedicine, vol. 11, pp. 1367-1382, 2016.

[124] P. Erica, L. Huinan, and J. W. Thomas, "Mimicking the nanofeatures of bone increases bone-forming cell adhesion and proliferation," Nanotechnology, vol. 16, no. 9, p. 1828, 2005.

[125] T. J. Webster, E. L. Hellenmeyer, and R. L. Price, "Increased osteoblast functions on theta+delta nanofiber alumina," Biomaterials, vol. 26, no. 9, pp. 953-960, 2005. 
[126] J. Y. Lim, A. D. Dreiss, Z. Zhou et al., "The regulation of integrinmediated osteoblast focal adhesion and focal adhesion kinase expression by nanoscale topography," Biomaterials, vol. 28, no. 10, pp. 1787-1797, 2007.

[127] J. Y. Lim, J. C. Hansen, C. A. Siedlecki, J. Runt, and H. J. Donahue, "Human foetal osteoblastic cell response to polymerdemixed nanotopographic interfaces," Journal of the Royal Society Interface, vol. 2, no. 2, pp. 97-108, 2005.

[128] Y. S. Park, K. Y. Yi, I. S. Lee, C. H. Han, and Y. C. Jung, “The effects of ion beam-assisted deposition of hydroxyapatite on the grit-blasted surface of endosseous implants in rabbit tibiae," Int J Oral Maxillofac Implants, vol. 20, no. 1, pp. 31-38, 2005.

[129] C. J. Wilson, R. E. Clegg, D. I. Leavesley, and M. J. Pearcy, "Mediation of biomaterial-cell interactions by adsorbed proteins: a review," Tissue Engineering, vol. 11, no. 1-2, pp. 1-18, 2005.

[130] M. S. Lord, M. Foss, and F. Besenbacher, "Influence of nanoscale surface topography on protein adsorption and cellular response," Nano Today, vol. 5, no. 1, pp. 66-78, 2010.

[131] S. N. Rodrigues, I. C. Goncalves, M. C. L. Martins, M. A. Barbosa, and B. D. Ratner, "Fibrinogen adsorption, platelet adhesion and activation on mixed hydroxyl-/methyl-terminated self-assembled monolayers," Biomaterials, vol. 27, no. 31, pp. 5357-5367, 2006.

[132] Y. Arima and H. Iwata, "Effect of wettability and surface functional groups on protein adsorption and cell adhesion using well-defined mixed self-assembled monolayers," Biomaterials, vol. 28, no. 20, pp. 3074-3082, 2007.

[133] K. R. Fath, C. J. Edgell, and K. Burridge, "The distribution of distinct integrins in focal contacts is determined by the substratum composition," Journal of Cell Science, vol. 92, pp. 6775, 1989.

[134] T. J. Webster, C. Ergun, R. H. Doremus, R. W. Siegel, and R. Bizios, "Specific proteins mediate enhanced osteoblast adhesion on nanophase ceramics," Journal of Biomedical Materials Research, vol. 51, no. 3, pp. 475-483, 2000.

[135] E. Ruoslahti, "RGD and other recognition sequences for integrins," Annual Review of Cell and Developmental Biology, vol. 12, pp. 697-715, 1996.

[136] E. A. Cavalcanti-Adam, T. Volberg, A. Micoulet, H. Kessler, B. Geiger, and J. P. Spatz, "Cell spreading and focal adhesion dynamics are regulated by spacing of integrin ligands," Biophysical Journal, vol. 92, no. 8, pp. 2964-2974, 2007.

[137] G. Maheshwari, G. Brown, D. A. Lauffenburger, A. Wells, and L. G. Griffith, "Cell adhesion and motility depend on nanoscale RGD clustering," Journal of Cell Science, vol. 113, no. 10, pp. 1677$1686,2000$.

[138] S. Tosatti, Z. Schwartz, C. Campbell et al., "RGD-containing peptide GCRGYGRGDSPG reduces enhancement of osteoblast differentiation by poly(L-lysine)-graft-poly(ethylene glycol)coated titanium surfaces," Journal of Biomedical Materials Research Part A, vol. 68, no. 3, pp. 458-472, 2004.

[139] K. Cai, J. Bossert, and K. D. Jandt, "Does the nanometre scale topography of titanium influence protein adsorption and cell proliferation?" Colloids and Surfaces B: Biointerfaces, vol. 49, no. 2, pp. 136-144, 2006.

[140] A. Curtis and C. Wilkinson, "New depths in cell behaviour: Reactions of cells to nanotopography," Biochemical Society Symposium, vol. 65, pp. 15-26, 1999.

[141] D. A. Lauffenburger and A. F. Horwitz, "Cell migration: a physically integrated molecular process," Cell, vol. 84, no. 3, pp. 359-369, 1996.
[142] E. Gongadze, D. Kabaso, S. Bauer et al., "Adhesion of osteoblasts to a nanorough titanium implant surface," International journal of nanomedicine, vol. 6, pp. 1801-1816, 2011.

[143] D. Kabaso, E. Gongadze, S. Perutkova et al., "Mechanics and electrostatics of the interactions between osteoblasts and titanium surface," Computer Methods in Biomechanics and Biomedical Engineering, vol. 14, no. 5, pp. 469-482, 2011.

[144] K. Anselme, P. Davidson, A. M. Popa, M. Giazzon, M. Liley, and L. Ploux, "The interaction of cells and bacteria with surfaces structured at the nanometre scale," Acta Biomaterialia, vol. 6, no. 10, pp. 3824-3846, 2010.

[145] O. Zinger, K. Anselme, A. Denzer et al., “Time-dependent morphology and adhesion of osteoblastic cells on titanium model surfaces featuring scale-resolved topography," Biomaterials, vol. 25, no. 14, pp. 2695-2711, 2004.

[146] A. S. Andersson, F. Bäckhed, A. von Euler, A. Richter-Dahlfors, D. Sutherland, and B. Kasemo, "Nanoscale features influence epithelial cell morphology and cytokine production," Biomaterials, vol. 24, no. 20, pp. 3427-3436, 2003.

[147] A. I. Teixeira, G. A. Abrams, P. J. Bertics, C. J. Murphy, and P. F. Nealey, "Epithelial contact guidance on well-defined microand nanostructured substrates," Journal of Cell Science, vol. 116, no. 10, pp. 1881-1892, 2003.

[148] M. J. Dalby, D. McCloy, M. Robertson, C. D. Wilkinson, and R. O. Oreffo, "Osteoprogenitor response to defined topographies with nanoscale depths," Biomaterials, vol. 27, no. 8, pp. 13061315, 2006.

[149] A. J. Dulgar-Tulloch, R. Bizios, and R. W. Siegel, "Human mesenchymal stem cell adhesion and proliferation in response to ceramic chemistry and nanoscale topography," Journal of Biomedical Materials Research A, vol. 90, no. 2, pp. 586-594, 2009.

[150] M. M. Stevens and J. H. George, "Exploring and engineering the cell surface interface," Science, vol. 310, no. 5751, pp. 1135-1138, 2005.

[151] G. Zhao, O. Zinger, Z. Schwartz, M. Wieland, D. Landolt, and B. D. Boyan, "Osteoblast-like cells are sensitive to submicron-scale surface structure," Clinical Oral Implants Research, vol. 17, no. 3, pp. 258-264, 2006.

[152] T. J. Webster, C. Ergun, R. H. Doremus, R. W. Siegel, and R. Bizios, "Enhanced osteoclast-like cell functions on nanophase ceramics," Biomaterials, vol. 22, no. 11, pp. 1327-1333, 2001.

[153] A. J. McManus, R. H. Doremus, R. W. Siegel, and R. Bizios, "Evaluation of cytocompatibility and bending modulus of nanoceramic/polymer composites," Journal of Biomedical Materials Research - Part A, vol. 72, no. 1, pp. 98-106, 2005.

[154] J. Lu and T. J. Webster, "Reduced immune cell responses on nano and submicron rough titanium," Acta Biomaterialia, vol. 16, no. 1, pp. 223-231, 2015.

[155] G. Colon, B. C. Ward, and T. J. Webster, "Increased osteoblast and decreased Staphylococcus epidermidis functions on nanophase $\mathrm{ZnO}$ and $\mathrm{TiO}_{2}$," Journal of Biomedical Materials Research Part A, vol. 78, no. 3, pp. 595-604, 2006.

[156] P. T. de Oliveira and A. Nanci, "Nanotexturing of titaniumbased surfaces upregulates expression of bone sialoprotein and osteopontin by cultured osteogenic cells," Biomaterials, vol. 25, no. 3, pp. 403-413, 2004.

[157] Q. Huang, T. A. Elkhooly, X. Liu et al., "Effects of hierarchical micro/nano-topographies on the morphology, proliferation and differentiation of osteoblast-like cells," Colloids and Surfaces B: Biointerfaces, vol. 145, pp. 37-45, 2016. 
[158] Aniket, R. Reid, B. Hall, I. Marriott, and A. El-Ghannam, "Early osteoblast responses to orthopedic implants: Synergy of surface roughness and chemistry of bioactive ceramic coating," Journal of Biomedical Materials Research Part A, vol. 103, no. 6, pp. 19611973, 2015.

[159] Wurihan, A. Yamada, D. Suzuki, Y. Shibata, R. Kamijo, and T. Miyazaki, "Enhanced in vitro biological activity generated by surface characteristics of anodically oxidized titanium-the contribution of the oxidation effect," European Cells and Materials, vol. 29, pp. 290-302, 2015.

[160] L. Trovato, M. Monti, C. del Fante et al., "A new medical device rigeneracons allows to obtain viable micro-grafts from mechanical disaggregation of human tissues," Journal of Cellular Physiology, vol. 230, no. 10, pp. 2299-2303, 2015.

[161] S. Rizzo, P. Zampetti, R. Rodriguez Y Baena, D. Svanosio, and S. M. Lupi, "Retrospective analysis of 521 endosseous implants placed under antibiotic prophylaxis and review of literature," Minerva Stomatologica, vol. 59, no. 3, pp. 75-88, 2010.

[162] S. M. Lupi, M. Cislaghi, S. Rizzo, and Y. B. R. Rodriguez, "Rehabilitation with implant-retained removable dentures and its effects on perioral aesthetics: a prospective cohort study," Clinical, Cosmetic and Investigational Dentistry, vol. 8, pp. 105110, 2016.

[163] A. M. Roos-Jansaker, C. Lindahl, H. Renvert, and S. Renvert, "Nine- to fourteen-year follow-up of implant treatment. Part I: implant loss and associations to various factors," Journal of Clinical Periodontology, vol. 33, no. 4, pp. 283-289, 2006.

[164] N. U. Zitzmann and T. Berglundh, "Definition and prevalence of peri-implant diseases," Journal of Clinical Periodontology, vol. 35, supplement 8, pp. 286-291, 2008.

[165] J. Meyle, G. Gersok, R.-H. Boedeker, and J. R. Gonzales, "Long-term analysis of osseointegrated implants in non-smoker patients with a previous history of periodontitis," Journal of Clinical Periodontology, vol. 41, no. 5, pp. 504-512, 2014.

[166] D. Cecchinato, A. Parpaiola, and J. Lindhe, "Mucosal inflammation and incidence of crestal bone loss among implant patients: a 10-year study," Clinical Oral Implants Research, vol. 25, no. 7, pp. 791-796, 2014.

[167] O. C. Koldsland, A. A. Scheie, and A. M. Aass, "Prevalence of peri-implantitis related to severity of the disease with different degrees of bone loss," Journal of Periodontology, vol. 81, no. 2, pp. 231-238, 2010.

[168] D. Cecchinato, A. Parpaiola, and J. Lindhe, "A cross-sectional study on the prevalence of marginal bone loss among implant patients," Clinical Oral Implants Research, vol. 24, no. 1, pp. 8790, 2013.

[169] A. M. Roos-Jansaker, C. Lindahl, H. Renvert, and S. Renvert, "Nine- to fourteen-year follow-up of implant treatment. Part II: presence of peri-implant lesions," Journal of Clinical Periodontology, vol. 33, no. 4, pp. 290-295, 2006.

[170] K. Swierkot, P. Lottholz, L. Flores-de-Jacoby, and R. Mengel, "Mucositis, peri-implantitis, implant success, and survival of implants in patients with treated generalized aggressive periodontitis: 3- to 16-year results of a prospective long-term cohort study," Journal of Periodontology, vol. 83, no. 10, pp. 1213-1225, 2012.

[171] F. O. Costa, S. Takenaka-Martinez, L. O. Cota, S. D. Ferreira, G. L. Silva, and J. E. Costa, "Peri-implant disease in subjects with and without preventive maintenance: a 5-year follow-up," Journal of Clinical Periodontology, vol. 39, no. 2, pp. 173-181, 2012.
[172] J. Mir-Mari, P. Mir-Orfila, R. Figueiredo, E. ValmasedaCastellon, and C. Gay-Escoda, "Prevalence of peri-implant diseases. a cross-sectional study based on a private practice environment," Journal of Clinical Periodontology, vol. 39, no. 5, pp. 490-494, 2012.

[173] L. A. Aguirre-Zorzano, R. Estefanía-Fresco, O. Telletxea, and M. Bravo, "Prevalence of peri-implant inflammatory disease in patients with a history of periodontal disease who receive supportive periodontal therapy," Clinical Oral Implants Research, vol. 26, no. 11, pp. 1338-1344, 2015.

[174] A. Mombelli, N. Müller, and N. Cionca, "The epidemiology of peri-implantitis," Clinical Oral Implants Research, vol. 23, supplement 6, pp. 67-76, 2012.

[175] M. A. Atieh, N. H. M. Alsabeeha, C. M. Faggion Jr., and W. J. Duncan, "The frequency of peri-implant diseases: a systematic review and meta-Analysis," Journal of Periodontology, vol. 84, no. 11, pp. 1586-1598, 2013.

[176] P. Astrand, J. Ahlqvist, J. Gunne, and H. Nilson, "Implant treatment of patients with edentulous jaws: a 20-year followup," Clinical Implant Dentistry and Related Research, vol. 10, no. 4, pp. 207-217, 2008.

[177] G. Schuldt Filho, H. R. Dalago, J. G. Oliveira de, K. Souza, S. Jovanovic, and M. A. Bianchini, "Prevalence of periimplantitis in patients with implant-supported fixed prostheses," Quintessence Int, vol. 45, no. 10, pp. 861-868, 2014.

[178] X. Hu, J. Luo, J. Li, L. Qiu, P. Di, and Y. Lin, "A 10-year retrospective analysis of clinical results of implant-retained/ supported prostheses in full edentulous patients," Zhonghua Kou Qiang Yi Xue Za Zhi, vol. 49, no. 6, pp. 333-338, 2014.

[179] T. Albrektsson, L. Canullo, D. Cochran, and H. De Bruyn, "Peri-implantitis': a complication of a foreign body or a manmade 'disease'. facts and fiction," Clinical Implant Dentistry and Related Research, vol. 18, no. 4, pp. 840-849, 2016.

[180] S. M. Lupi, M. Granati, A. Butera, V. Collesano, and Y. B. R. Rodriguez, "Air-abrasive debridement with glycine powder versus manual debridement and chlorhexidine administration for the maintenance of peri-implant health status: a six-month randomized clinical trial," International Journal of Dental Hygiene, 2016.

[181] A. Mombelli, M. A. van Oosten, E. Schurch Jr., and N. P. Land, "The microbiota associated with successful or failing osseointegrated titanium implants," Oral Microbiol Immunol, vol. 2, no. 4, pp. 145-151, 1987.

[182] W. Becker, B. E. Becker, M. G. Newman, and S. Nyman, "Clinical and microbiologic findings that may contribute to dental implant failure," Int J Oral Maxillofac Implants, vol. 5, no. 1, pp. 31-38, 1990.

[183] M. Quiryen and M. A. Listgarten, “The distribution of bacterial morphotypes around natural teeth and titanium implants ad modum Branemark," Clinical Oral Implants Research, vol. 1, no. 1, pp. 8-12, 1990.

[184] G. A. Alcoforado, T. E. Rams, D. Feik, and J. Slots, "Microbial aspects of failing osseointegrated dental implants in humans," Journal de Parodontologie, vol. 10, no. 1, pp. 11-18, 1991.

[185] T. Berglundh, J. Lindhe, I. Ericsson, C. P. Marinello, B. Liljenberg, and P. Thornsen, "The soft tissue barrier at implants and teeth," Clinical Oral Implants Research, vol. 2, no. 2, pp. 81-90, 1991.

[186] T. Berglundh, J. Lindhe, C. Marinello, I. Ericsson, and B. Liljenberg, "Soft tissue reaction to de novo plaque formation on implants and teeth. An experimental study in the dog," Clinical Oral Implants Research, vol. 3, no. 1, pp. 1-8, 1992. 
[187] I. Ericsson, T. Berglundh, C. Marinello, B. Liljenberg, and J. Lindhe, "Long-standing plaque and gingivitis at implants and teeth in the dog," Clinical Oral Implants Research, vol. 3, no. 3, pp. 99-103, 1992.

[188] A. Leonhardt, T. Berglundh, I. Ericsson, and G. Dahlen, "Putative periodontal and teeth in pathogens on titanium implants and teeth in experimental gingivitis and periodontitis in beagle dogs," Clinical Oral Implants Research, vol. 3, no. 3, pp. 112-119, 1992.

[189] J. Lindhe, T. Berglundh, I. Ericsson, B. Liljenberg, and C. P. Marinello, "Experimental breakdown of peri-implant and periodontal tissues. A study in the beagle dog," Clinical Oral Implants Research, vol. 3, no. 1, pp. 9-16, 1992.

[190] E. S. Ong, H. N. Newman, M. Wilson, and J. S. Bulman, "The occurrence of periodontitis-related microorganisms in relation to titanium implants," Journal of Periodontology, vol. 63, no. 3, pp. 200-205, 1992.

[191] R. Pontoriero, M. P. Tonelli, G. Carnevale, A. Mombelli, S. R. Nyman, and N. P. Lang, "Experimentally induced peri-implant mucositis. A clinical study in humans.," Clinical Oral Implants Research, vol. 5, no. 4, pp. 254-259, 1994.

[192] J. M. Salcetti, J. D. Moriarty, L. F. Cooper et al., "The clinical, microbial, and host response characteristics of the failing implant," International Journal of Oral and Maxillofacial Implants, vol. 12, no. 1, pp. 32-42, 1997.

[193] P. I. Eke, L. D. Braswell, and M. E. Fritz, "Microbiota Associated with Experimental Peri-Implantitis and Periodontitis in Adult Macaca mulatta Monkeys," Journal of Periodontology, vol. 69, no. 2, pp. 190-194, 1998.

[194] M. Esposito, J. M. Hirsch, U. Lekholm, and P. Thomsen, "Biological factors contributing to failures of osseointegrated oral implants: (II). Etiopathogenesis," European Journal of Oral Sciences, vol. 106, no. 3, pp. 721-764, 1998.

[195] M. A. Listgarten and C. H. Lai, "Comparative microbiological characteristics of failing implants and periodontally diseased teeth," Journal of Periodontology, vol. 70, no. 4, pp. 431-437, 1999.

[196] M. Quirynen and C. M. Bollen, "The influence of surface roughness and surface-free energy on supra- and subgingival plaque formation in man. A review of the literature.," Journal of Clinical Periodontology, vol. 22, no. 1, pp. 1-14, 1995.

[197] K. H. Lee, M. F. J. Maiden, A. C. R. Tanner, and H. P. Weber, "Microbiota of successful osseonintegrated dental implants," Journal of Periodontology, vol. 70, no. 2, pp. 131-138, 1999.

[198] G. N. Belibasakis, "Microbiological and immuno-pathological aspects of peri-implant diseases," Archives of Oral Biology, vol. 59, no. 1, pp. 66-72, 2014.

[199] D. E. Caldwell, E. Atuku, D. C. Wilkie et al., "Germ theory vs. community theory in understanding and controlling the proliferation of biofilms," Advances in dental research, vol. 11, no. 1, pp. 4-13, 1997.

[200] P. S. Stewart and J. W. Costerton, "Antibiotic resistance of bacteria in biofilms," The Lancet, vol. 358, no. 9276, pp. 135-138, 2001.

[201] N. Cerca, S. Martins, and F. Cerca, "Comparative assessment of antibiotic susceptibility of coagulase-negative staphylococci in biofilm versus planktonic culture as assessed by bacterial enumeration or rapid XTT colorimetry," Journal of Antimicrobial Chemotherapy, vol. 56, no. 2, pp. 331-336, 2005.

[202] M. Quirynen, M. De Soete, and D. van Steenberghe, "Infectious risks for oral implants: a review of the literature," Clinical Oral Implants Research, vol. 13, no. 1, pp. 1-19, 2002.
[203] J. A. Shibli, L. Melo, D. S. Ferrari, L. C. Figueiredo, M. Faveri, and M. Feres, "Composition of supra- and subgingival biofilm of subjects with healthy and diseased implants," Clinical Oral Implants Research, vol. 19, no. 10, pp. 975-982, 2008.

[204] L. J. A. Heitz-Mayfield and N. P. Lang, "Comparative biology of chronic and aggressive periodontitis vs. peri-implantitis," Periodontology 2000, vol. 53, no. 1, pp. 167-181, 2010.

[205] L. Sbordone and C. Bortolaia, "Oral microbial biofilms and plaque-related diseases: microbial communities and their role in the shift from oral health to disease.," Clinical Oral Investigations, vol. 7, no. 4, pp. 181-188, 2003.

[206] S. S. Socransky, A. D. Haffajee, M. A. Cugini, C. Smith, and R. L. Kent Jr., "Microbial complexes in subgingival plaque," Journal of Clinical Periodontology, vol. 25, no. 2, pp. 134-144, 1998.

[207] M. Quirynen, R. Vogels, W. Peeters, D. Van Steenberghe, I. Naert, and A. Haffajee, "Dynamics of initial subgingival colonization of 'pristine' peri-implant pockets," Clinical Oral Implants Research, vol. 17, no. 1, pp. 25-37, 2006.

[208] M. Yoshinari, Y. Oda, T. Kato, and K. Okuda, "Influence of surface modifications to titanium on antibacterial activity in vitro," Biomaterials, vol. 22, no. 14, pp. 2043-2048, 2001.

[209] S. D. Puckett, E. Taylor, T. Raimondo, and T. J. Webster, "The relationship between the nanostructure of titanium surfaces and bacterial attachment," Biomaterials, vol. 31, no. 4, pp. 706713, 2010.

[210] G. Nakazato, H. Tsuchiya, M. Sato, and M. Yamauchi, "In vivo plaque formation on implant materials," Int J Oral Maxillofac Implants, vol. 4, no. 4, pp. 321-326, 1989.

[211] C. D. Wu-Yuan, K. J. Eganhouse, J. C. Keller, and K. S. Walters, "Oral bacterial attachment to titanium surfaces: a scanning electron microscopy study," J Oral Implantol, vol. 21, no. 3, pp. 207-213, 1995

[212] W. Teughels, N. Van Assche, I. Sliepen, and M. Quirynen, "Effect of material characteristics and/or surface topography on biofilm development," Clinical Oral Implants Research, vol. 17, Supplement 2, pp. 68-81, 2006.

[213] K. A. Whitehead, J. Colligon, and J. Verran, "Retention of microbial cells in substratum surface features of micrometer and sub-micrometer dimensions," Colloids and Surfaces B: Biointerfaces, vol. 41, no. 2-3, pp. 129-138, 2005.

[214] R. Burgers, T. Gerlach, S. Hahnel, F. Schwarz, G. Handel, and M. Gosau, "In vivo and in vitro biofilm formation on two different titanium implant surfaces," Clinical Oral Implants Research, vol. 21, no. 2, pp. 156-164, 2010.

[215] C. Elter, W. Heuer, A. Demling et al., "Supra- and subgingival biofilm formation on implant abutments with different surface characteristics," International Journal of Oral and Maxillofacial Implants, vol. 23, no. 2, pp. 327-334, 2008.

[216] R. Xing, S. P. Lyngstadaas, J. E. Ellingsen, S. Taxt-Lamolle, and H. J. Haugen, "The influence of surface nanoroughness, texture and chemistry of TiZr implant abutment on oral biofilm accumulation," Clinical Oral Implants Research, vol. 26, no. 6, pp. 649-656, 2015.

[217] M. Quirynen, C. M. Bollen, W. Papaioannou, J. Van Eldere, and D. van Steenberghe, "The influence of titanium abutment surface roughness on plaque accumulation and gingivitis: short-term observations," The International Journal of Oral \& Maxillofacial Implants, vol. 11, no. 2, pp. 169-178, 1996.

[218] C. M. Bollen, W. Papaioanno, J. Van Eldere, E. Schepers, M. Quirynen, and D. van Steenberghe, "The influence of abutment surface roughness on plaque accumulation and peri-implant mucositis," Clin Oral Implants Res, vol. 7, no. 3, pp. 201-211, 1996. 
[219] V. Frojd, V. Franke-Stenport, L. Meirelles, and A. Wennerberg, "Increased bone contact to a calcium-incorporated oxidized commercially pure titanium implant: an in-vivo study in rabbits," The International Journal of Oral and Maxillofacial Surgery, vol. 37, no. 6, pp. 561-566, 2008.

[220] V. Frojd, P. Linderback, A. Wennerberg, L. Chavez de Paz, G. Svensater, and J. R. Davies, "Effect of nanoporous $\mathrm{TiO}_{2}$ coating and anodized $\mathrm{Ca}^{2+}$ modification of titanium surfaces on early microbial biofilm formation," BMC Oral Health, vol. 11, no. 8, 2011.

[221] C. Wickstörm, M. C. Herzberg, D. Beighton, and G. Svensater, "Proteolytic degradation of human salivary MUC5B by dental biofilms," Microbiology, vol. 155, no. 9, pp. 2866-2872, 2009.

[222] F. Zhang, Z. Zhang, X. Zhu, E. T. Kang, and K. G. Neoh, "Silk-functionalized titanium surfaces for enhancing osteoblast functions and reducing bacterial adhesion," Biomaterials, vol. 29, no. 36, pp. 4751-4759, 2008.

[223] Z. Peng, J. Ni, K. Zheng et al., "Dual effects and mechanism of $\mathrm{TiO}_{2}$ nanotube arrays in reducing bacterial colonization and enhancing C3H10T1/2 cell adhesion," International Journal of Nanomedicine, vol. 8, pp. 3093-3105, 2013.

[224] L. Drago, M. Bortolin, E. De Vecchi et al., "Antibiofilm activity of sandblasted and laser-modified titanium against microorganisms isolated from peri-implantitis lesions," Journal of Chemotherapy, vol. 28, no. 5, pp. 383-389, 2016.

[225] A. V. Singh, V. Vyas, R. Patil et al., "Quantitative characterization of the influence of the nanoscale morphology of nanostructured surfaces on bacterial adhesion and biofilm formation," PLoS ONE, vol. 6, no. 9, Article ID e25029, 2011.

[226] W.-T. Lin, Y.-Y. Zhang, H.-L. Tan et al., "Inhibited bacterial adhesion and biofilm formation on quaternized chitosanloaded titania nanotubes with various diameters," Materials, vol. 9, no. 3, article no. 155, 2016.

[227] R. P. Carlson, R. Taffs, W. M. Davison, and P. S. Stewart, "Anti-biofilm properties of chitosan-coated surfaces," Journal of Biomaterials Science, Polymer Edition, vol. 19, no. 8, pp. 10351046, 2008.

[228] M. Kong, X. G. Chen, K. Xing, and H. J. Park, “Antimicrobial properties of chitosan and mode of action: a state of the art review," International Journal of Food Microbiology, vol. 144, no. 1, pp. 51-63, 2010.

[229] H. Liu, Y. Du, X. Wang, and L. Sun, "Chitosan kills bacteria through cell membrane damage," International Journal of Food Microbiology, vol. 95, no. 2, pp. 147-155, 2004.

[230] V. Sainz, J. Conniot, A. I. Matos et al., "Regulatory aspects on nanomedicines," Biochemical and Biophysical Research Communications, vol. 468, no. 3, pp. 504-510, 2015.

[231] H. Shi, R. Magaye, V. Castranova, and J. Zhao, "Titanium dioxide nanoparticles: a review of current toxicological data," Particle and Fibre Toxicology, vol. 10, no. 1, article 15, 2013.

[232] H. Matusiewicz, "Potential release of in vivo trace metals from metallic medical implants in the human body: from ions to nanoparticles-a systematic analytical review," Acta Biomaterialia, vol. 10, no. 6, pp. 2379-2403, 2014.

[233] S. M. Lupi, D. Zaffe, R. R. Y. Baena, S. Rizzo, and A. R. Botticelli, "Cytopathological and chemico-physical analyses of smears of mucosa surrounding oral piercing," Oral Diseases, vol. 16, no. 2, pp. 160-166, 2010.

[234] S. T. Stern, P. P. Adiseshaiah, and R. M. Crist, "Autophagy and lysosomal dysfunction as emerging mechanisms of nanomaterial toxicity," Particle and Fibre Toxicology, vol. 9, article no. 20, 2012.
[235] V. R. Lopes, V. Loitto, J.-N. Audinot, N. Bayat, A. C. Gutleb, and S. Cristobal, "Dose-dependent autophagic effect of titanium dioxide nanoparticles in human $\mathrm{HaCaT}$ cells at non-cytotoxic levels," Journal of Nanobiotechnology, vol. 14, no. 1, article no. 22, 2016.

[236] R. Garcia-Contreras, R. J. Scougall-Vilchis, R. ContrerasBulnes, Y. Kanda, H. Nakajima, and H. Sakagami, "Induction of prostaglandin $\mathrm{E} 2$ production by $\mathrm{TiO}_{2}$ nanoparticles in human gingival fibroblast," In Vivo, vol. 28, no. 2, pp. 217-222, 2014.

[237] A. R. Ribeiro, S. Gemini-Piperni, R. Travassos et al., "Trojanlike internalization of anatase titanium dioxide nanoparticles by human osteoblast cells," Scientific Reports, vol. 6, Article ID 23615, 2016.

[238] B. Sha, W. Gao, S. Wang et al., "Nano-titanium dioxide induced cardiac injury in rat under oxidative stress," Food and Chemical Toxicology, vol. 58, pp. 280-288, 2014.

[239] S. W. Fage, J. Muris, S. S. Jakobsen, and J. P. Thyssen, “Titanium: A review on exposure, release, penetration, allergy, epidemiology, and clinical reactivity," Contact Dermatitis, 2016.

[240] R. Baan, K. Straif, Y. Grosse et al., "Carcinogenicity of carbon black, titanium dioxide, and talc," The Lancet Oncology, vol. 7, no. 4, pp. 295-296, 2006.

[241] M. Topolovec, A. Cor, and I. Milosev, "Metal-on-metal vs. metal-on-polyethylene total hip arthroplasty tribological evaluation of retrieved components and periprosthetic tissue," Journal of the Mechanical Behavior of Biomedical Materials, vol. 34, pp. 243-252, 2014.

[242] I. Milosev and M. Remskar, "In vivo production of nanosized metal wear debris formed by tribochemical reaction as confirmed by high-resolution TEM and XPS analyses," Journal of Biomedical Materials Research Part A, vol. 91, no. 4, pp. 11001110, 2009.

[243] SCENIHR and S. C. o. E. a. N. I. H. Risks), "Final Opinion on the Guidance on the Determination of Potential Health Effects of Nanomaterials Used in Medical Devices," January 2015.

[244] K. Rasmussen, M. Gonzalez, P. Kearns, J. R. Sintes, F. Rossi, and P. Sayre, "Review of achievements of the OECD Working Party on Manufactured Nanomaterials' Testing and Assessment Programme. From exploratory testing to test guidelines," Regulatory Toxicology and Pharmacology, vol. 74, pp. 147-160, 2016.

[245] P. E. Murray, C. Garcia Godoy, and F. Garcia Godoy, "How is the biocompatibilty of dental biomaterials evaluated?" Med Oral Patol Oral Cir Bucal, vol. 12, no. 3, pp. E258-E266, 2007.

[246] J. C. Wataha, Restorative Dental Materials, St. Louis Mosby, 2002.

[247] K. Moharamzadeh, I. M. Brooki, and R. Van Noortr, "Biocompatibility of resin-based dental materials," Materials, vol. 2, no. 2, pp. 514-548, 2009. 

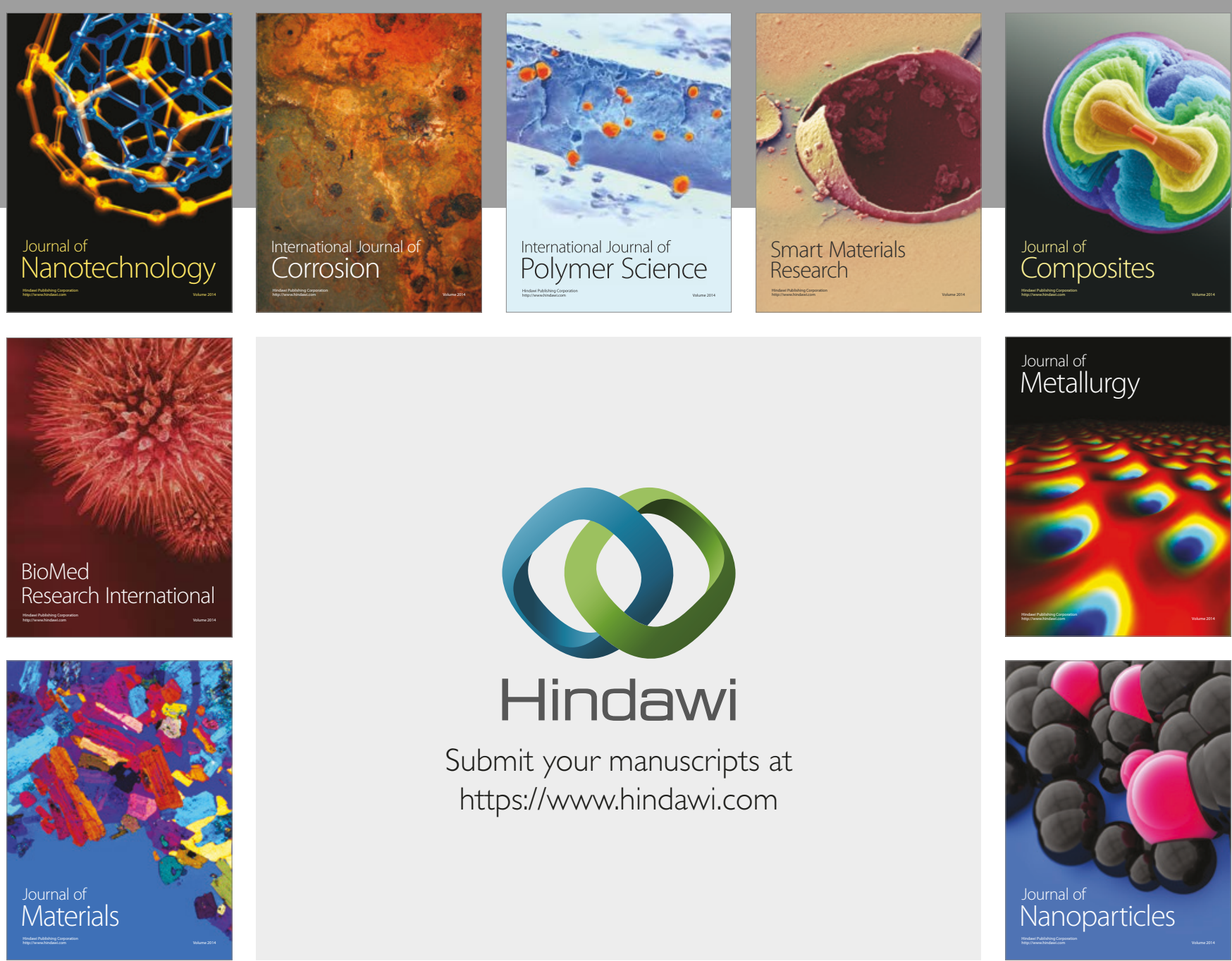

\section{Hindawi}

Submit your manuscripts at

https://www.hindawi.com
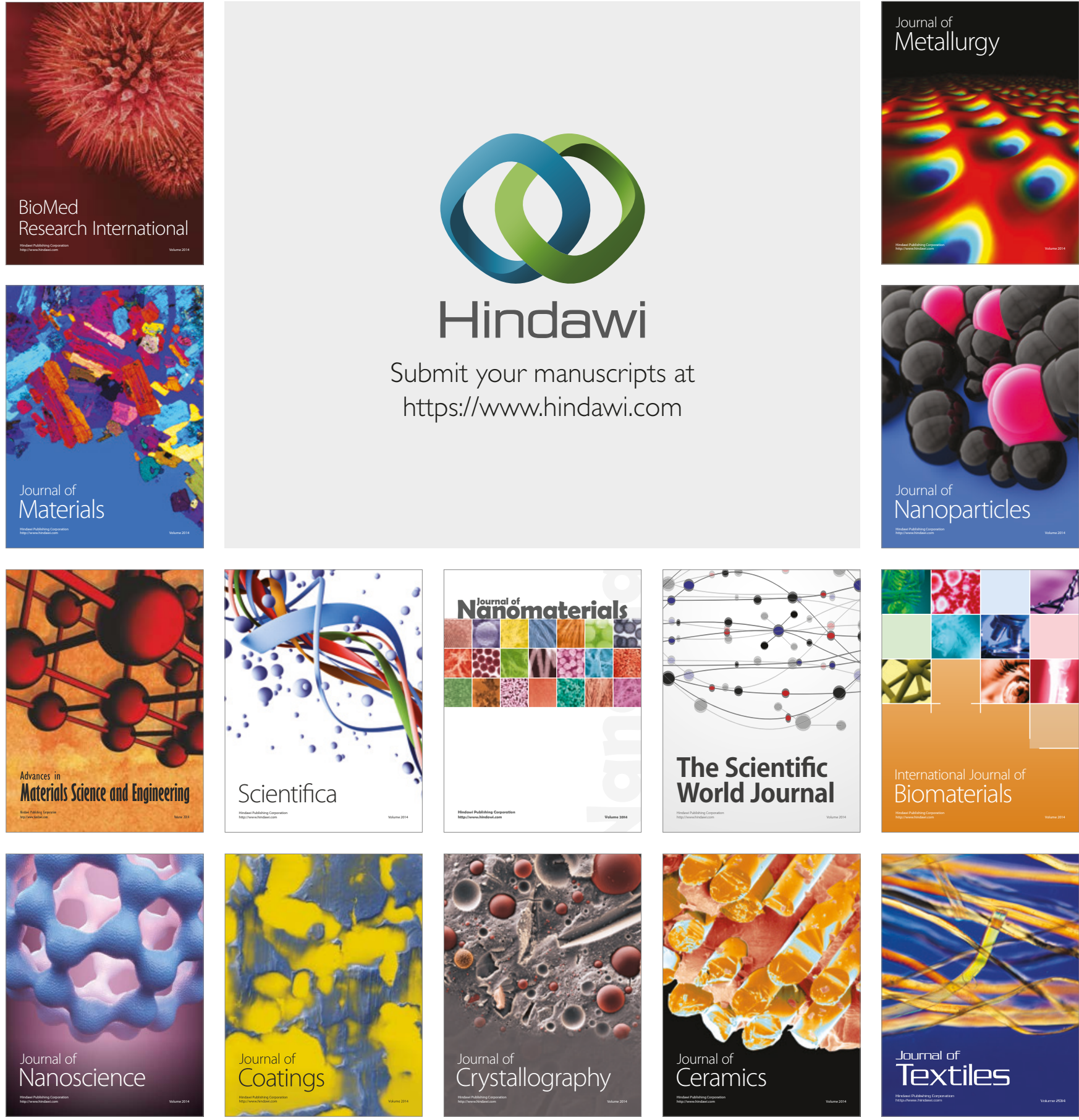

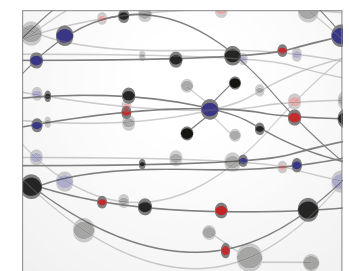

The Scientific World Journal
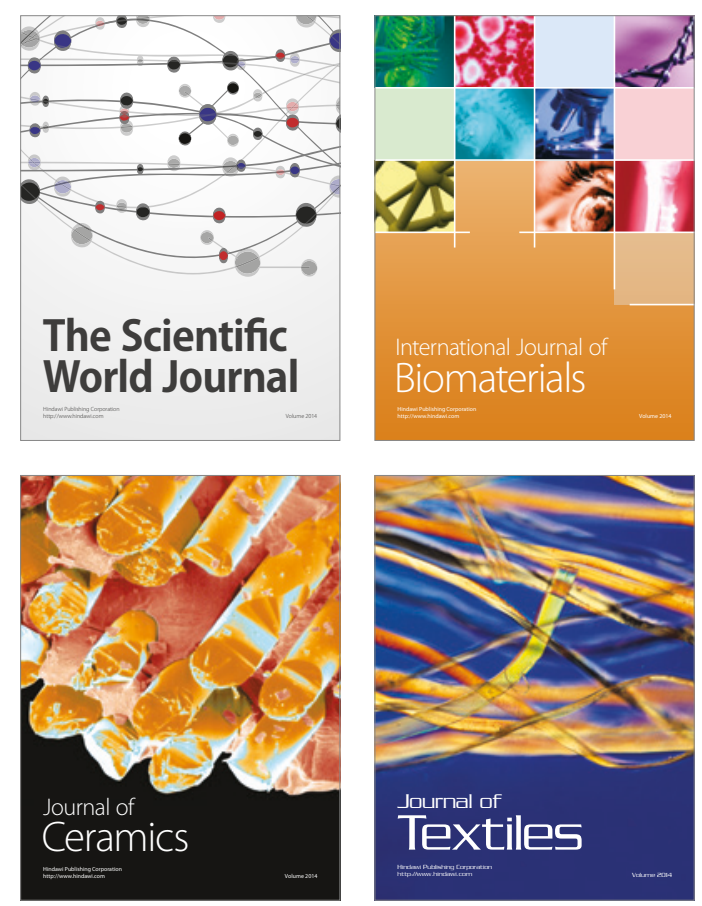